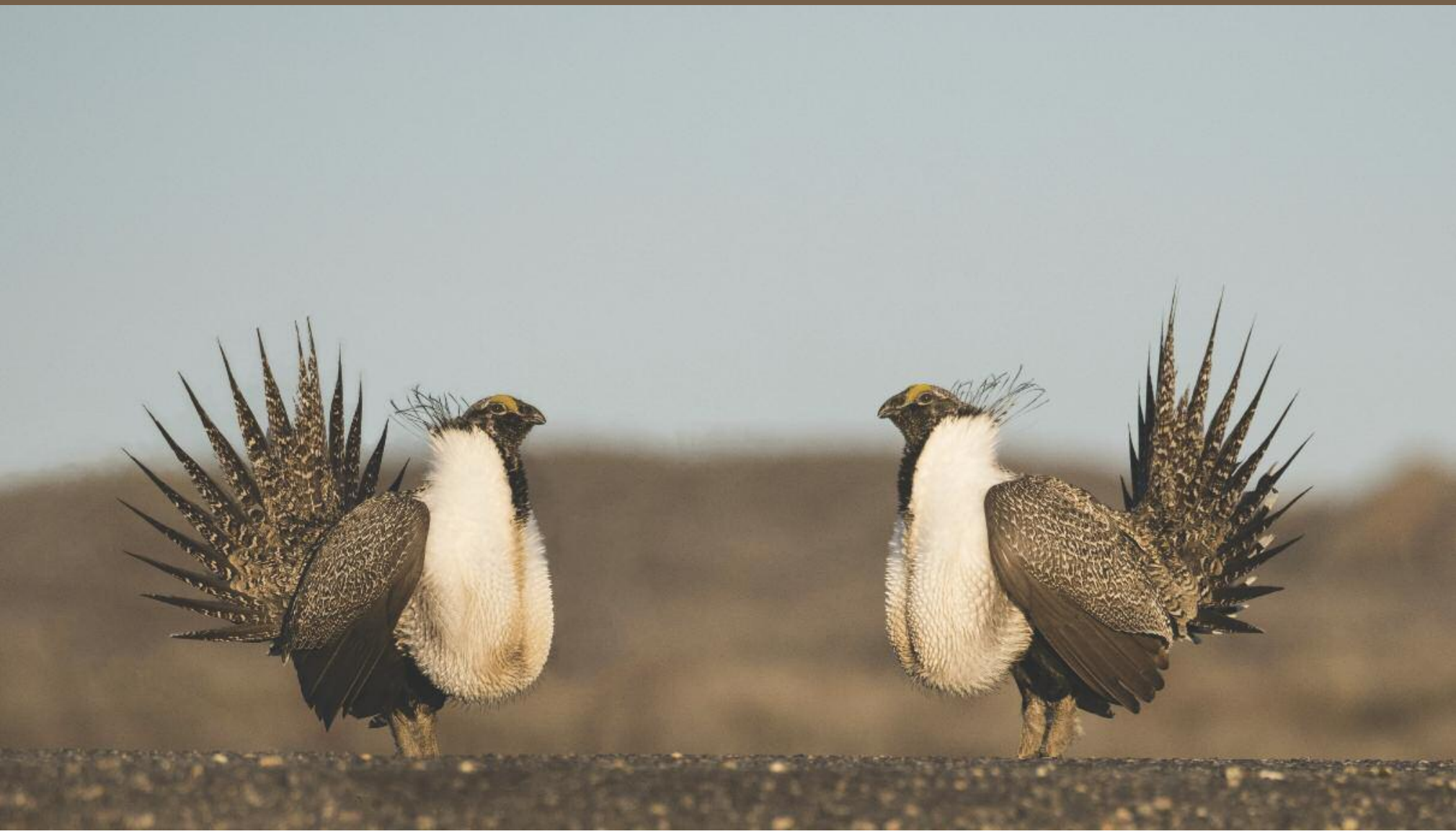

Male Greater Sage-Grouse displaying on their lek near St Anthony, Idaho. Photo by Brian Perkes 


\title{
Conserving and restoring habitat for Greater Sage-Grouse and other sagebrush-obligate wildlife: the crucial link of forbs and sagebrush diversity
}

\author{
R Kasten Dumroese, Tara Luna, Bryce A Richardson, Francis F Kilkenny, and Justin B Runyon
}

In the western US, Greater Sage-Grouse (Centrocercus urophasianus Bonaparte [Phasianidae]) have become an indicator species of the overall health of the sagebrush (Artemisia L. [Asteraceae]) dominated communities that support a rich diversity of flora and fauna. This species has an integral association with sagebrush, its understory forbs and grasses, and the invertebrate community dependent on that flora. Adult birds and their growing chicks consume a wide variety of understory species, and the invertebrates that develop on this flora are an important source of protein, especially for developing broods. Restoration plans for degraded sagebrush communities must consider outplanting the correct species and seed source of sagebrush and its diverse array of native forbs. Changes in climate and the problem with invasive species, especially annual grasses that spawn large-scale fires, will need to be addressed so that restoration efforts can succeed.

Dumroese RK, Luna T, Richardson BA, Kilkenny FF, Runyon JB. 2015. Conserving and restoring habitat for Greater Sage-Grouse and other sagebrush-obligate wildlife: the crucial link of forbs and sagebrush diversity. Native Plants Journal 16(3):277-299.

\section{KEY WORDS}

Centrocercus urophasianus, Artemisia, habitat, restoration, forbs, invasive species

NOMENCLATURE

Plants: USDA NRCS (2015)

Fungi: Farr and Rossman (2015)

Animals: ITIS (2015)

Birds: AOU (2015)

This open access article is distributed under the terms of the CC BY NC ND license (http://creativecommons.org/licenses/byncnd/3.0) and is freely available online at: http://npj.uwpress.org 
nce covering 69 million ha (170 million ac) in 16

states and 3 provinces, quality sagebrush (Artemisia L. [Asteraceae]) habitat is now an imperiled ecosystem in the US (Noss and others 1995). Native floras of the sagebrush biome are remarkably diverse and species rich, with numerous endemic genera and species (Figure 1). Collectively, these areas contain more than 5000 plant taxa (Cronquist and others 1972-2012; Hitchcock and others 1987; Baldwin and others 2002, 2012). They are centers of diversity for a significant number of monotypic and species-rich genera (Table 1), many of which are narrow or regional endemics, and new species are still being discovered, such as Lomatium ochocense Helliwell \& Constance (Apiaceae) from central Oregon (Helliwell 2010).

This diverse flora in turn supports a diverse invertebrate community including herbivores, predators, detritivores, important pollinators of regional flora, and the western population of the monarch butterfly (Danaus plexippus L. [Lepidoptera: Nymphalidae]). Together, the diverse flora and invertebrate community support numerous obligate wildlife species such as the pygmy rabbit (Brachylagus idahoensis Merriam [Leporidae]), sagebrush vole (Lemmiscus curtatus Cope

\section{TABLE 1}

Forb genera with high species diversity within the sagebrush biome of western North America.

\begin{tabular}{ll} 
Genus and authority & Family \\
\hline Allium L. & Liliaceae \\
Astragalus L. & Fabaceae \\
Calochortus Pursh & Liliaceae \\
Castilleja Mutis ex L.f. & Scrophulariaceaez \\
Eriogonum Michx. & Polygonaceae \\
Lomatium Raf. & Apiaceae \\
Lupinus L. & Fabaceae \\
Penstemon Schmidel & Scrophulariaceae \\
Phlox L. & Polemoniaceae \\
Trifolium L. & Fabaceae \\
Multiple genera & Asteraceae
\end{tabular}

z ITIS (2015) places Castilleja in the Orobanchaceae and Penstemon in the Plantaginaceae.

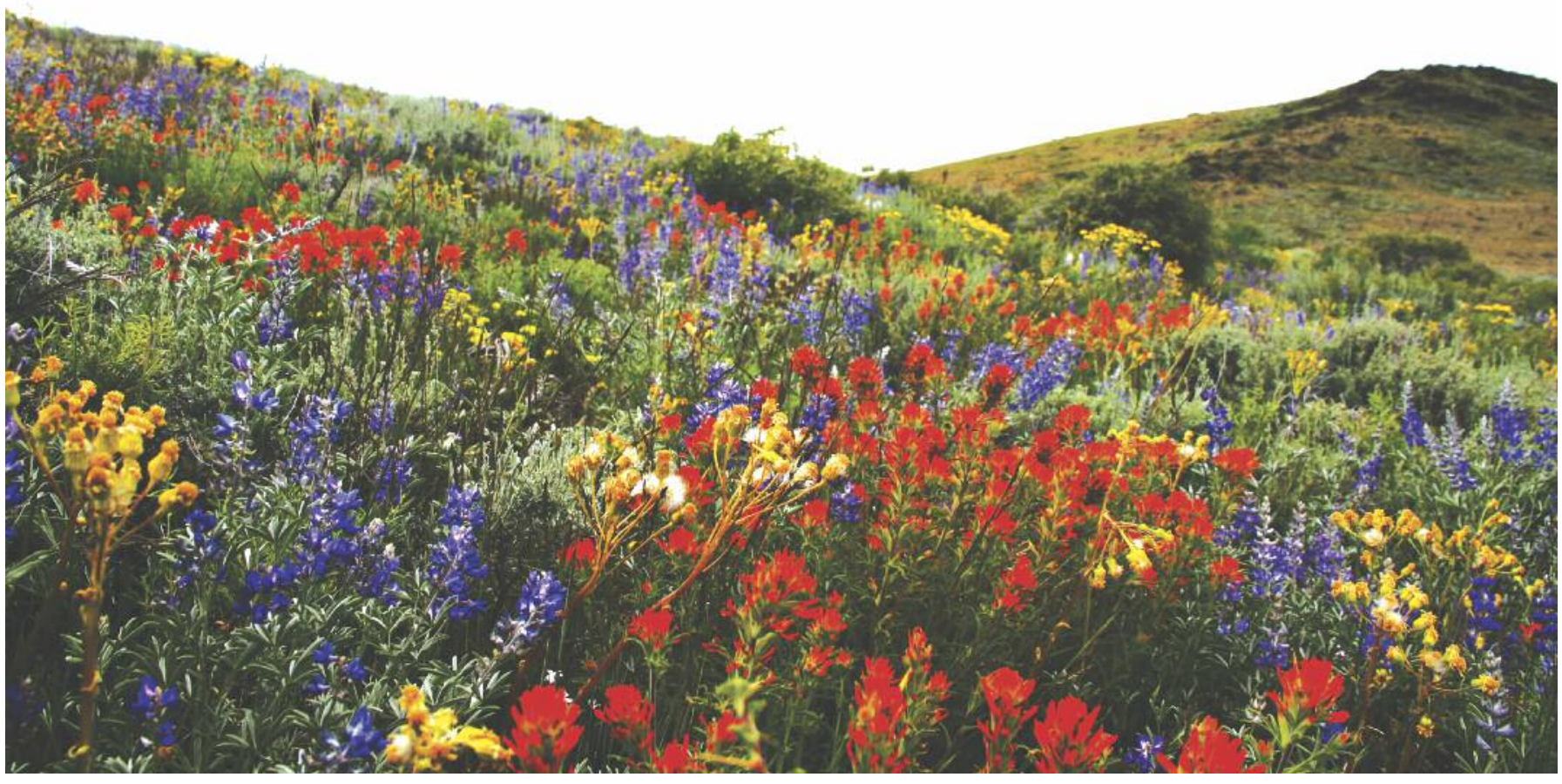

Figure 1. Greater Sage-Grouse habitat in the Virginia Mountains of Nevada. Photo by Steven Schwarzbach, US Geological Survey 
[Cricetidae]), pronghorn (Antilocapra americana Ord [Antilocapridae]), Sagebrush Sparrow (Artemisiospiza nevadensis Bruant des armoises), Sage Thrasher (Oreoscoptes montanus JK Townsend [Mimidae]), and more than 200 species of other resident and migratory birds.

Of the birds of the sagebrush biome, the Greater SageGrouse (Centrocercus urophasianus Bonaparte [Phasianidae]) and Gunnison Sage-Grouse (Centrocercus minimus Young and others) have become "canaries in the coal mine" as indicators for the health of the North American sagebrush landscape. These 2 species of sage-grouse have a remarkable life history entwined with sagebrush. Males assemble in areas called "leks" during the breeding season (late winter through spring) to court females with their spectacular mating displays (Figure 2). Nesting hens, brooding females, and chicks rely directly on a high diversity of annual and perennial forbs; sage-grouse diet of those forbs and the biodiverse, high-protein invertebrates associated with the plants is critical for the species survival.

In 1805, near the confluence of the Marias and Missouri Rivers, Meriwether Lewis remarked, I saw a large flock of the mountain cock, or a large species of heath hen with a long pointed tail that the Indians informed us were common to the Rocky Mountains, and later that winter, the Cock of the Plains is found in the Plains of the Columbia and are in great abundance from the s.e. fork of the Columbia to that of Clark's River [Clark Fork River].

Today, the Gunnison Sage-Grouse roams the Colorado Plateau, whereas the Greater Sage-Grouse (GRSG) occurs in just half of its original range in the Great Basin, Columbia River Basin, and Wyoming Basin and some areas of the northern and western Great Plains. Gunnison Sage-Grouse was listed as

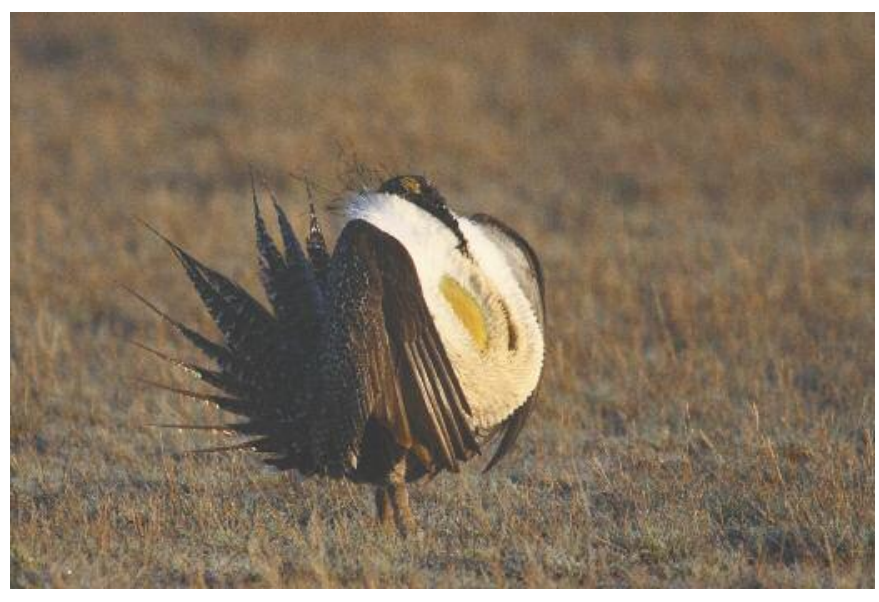

Figure 2. A displaying male Greater Sage-Grouse on a lek in Butte County, South Dakota. Photo by Steve Fairbairn, US Fish \& Wildlife Service threatened under the Endangered Species Act (ESA) in 2014 (Federal Register 2014). Although listing GRSG under the ESA was recently deemed not warranted, its status will be re-evaluated in 5 y (USDI 2015). Today, most remaining GRSG populations are associated with habitats at more northern latitudes or higher elevations, and (or) within more mesic or colder sagebrush environments (Connelly and Braun 1997).

Because Gunnison Sage-Grouse and GRSG are believed to have similar life histories and habitat requirements and because most literature concentrates on GRSG, the focus of this paper will be on GRSG, recognizing that key points are most likely applicable to Gunnison Sage-Grouse, too. Our objectives are to demonstrate to nursery managers, seed producers, and land managers the importance of floral diversity to sustainable populations of both sage-grouse species (Gunnison and Greater) and to encourage those professionals to produce and deploy more native plants, especially forbs, in habitat restoration efforts.

\section{THREATS TO SAGE-GROUSE}

A suite of threats are affecting sage-grouse; these threats are often broadly lumped together as the loss, fragmentation, and degradation of sagebrush ecosystems, which are primarily driven by human activities (Connelly and others 2011). These anthropogenic activities are now interacting in complex ways (see Finch and others 2015 for a concise review), and important drivers include invasive annual grasses, encroachment by trees, altered fire cycles, grazing, and climate change (Davies and others 2011). The decades of chronic loss, fragmentation, and degradation within the sagebrush ecosystem has led to the acute potential problem of several sagebrush obligate wildlife species being considered for threatened or endangered status at the state and federal levels, which would have a large implication on the management and use of western rangelands. Two other drivers in the current discussion are pesticides and energy development.

By the 1970s, more than 2 million ha (nearly 5 million ac) of sagebrush had been mechanically treated, sprayed with herbicides, or burned to improve grazing (Hull and others 1952; Schneegas 1967; Vale 1974), often during spring and early summer at the height of GRSG nesting and brood rearing, resulting in declines in sage-grouse populations and habitat quality (Connelly and others 2000; Beck and others 2003, 2012; Crawford and others 2004). These treatments also negatively affected populations of understory native floras, health of biological soil crusts, and persistence of native seedbanks (Belnap and Eldridge 2003; Thacker and others 2012).

Herbicide use is a factor for GRSG survival. 2,4-D is a very commonly used phenoxy herbicide used for control of broadleaf plants in rangelands. Perennial forbs important to the dietary requirements of pre-laying hens, chicks, and juveniles, such as those in the species-rich Asteraceae, Liliaceae, Rosaceae, 
Plantaginaceae, Orobanchaceae, and Fabaceae that support entire communities including a web of regional pollinators, are severely damaged or killed by 2,4-D. In addition, modern formulations of 2,4-D are highly toxic to bees (Hymenoptera) (Dow Chemical Company 2015), which may have long-term implications for forb reproduction if pollination services are hindered. It may take several years for annual plant recovery or recruitment following 2,4-D application (Thacker and others 2012). Broadleaf herbicides can also have long-term effects on remaining native perennials. Picloram, for example, reduced flowering of established arrowleaf balsamroot (Balsamorhiza sagittata (Pursh) Nutt. [Asteraceae]) plants and occurrence of new seedlings for at least $4 \mathrm{y}$ after application (Crone and others 2009). Sites with herbicide-reduced cover of native vegetation are vulnerable to infestation by invasive annual grasses, such as cheatgrass (Bromus tectorum L. [Poaceae]).

Insecticides, such as those used to control grasshoppers (Orthoptera: Acrididae) (Johnson and Boyce 1990) and Mormon crickets (Anabrus simplex Haldeman [Orthoptera: Tettigoniidae]), can be toxic to adult birds (Blus and others 1989), and low rates of annual GRSG recruitment, especially in areas where sagebrush habitat interfaces agricultural fields, may be attributable to insecticides. Juveniles are attracted to agricultural fields during late summer months (Peterson 1970) after many preferred native forbs have senesced for the season.

In addition, oil, gas, coal, and wind energy development in sagebrush-dominated habitats during the past $20 \mathrm{y}$ has nega- tively affected GRSG. Holloran (2005) noted that the number of producing wells has more than doubled, and this development in sagebrush habitat far exceeds GRSG tolerance thresholds. Unfortunately, current energy expansion is occurring in some of the best remaining sagebrush communities and within areas having the highest density populations of GRSG and other sagebrush-obligate species (Knick and others 2003; Crawford and others 2004; Kaiser 2006; Bergquist and others 2007). Threats to GRSG associated with energy development include a number of detrimental effects: increased fragmentation leading to disrupted habitat use patterns (Lyon and Anderson 2003; Ingelfinger and Anderson 2004; Aldridge and Boyce 2007; Walker and others 2007; Doherty and others 2008: Blickley and others 2012; LeBeau 2012), increased chick mortality proximate to oil and gas projects (Aldridge and Boyce 2007), increased invasive plant establishment along roads (Gelbard and Belnap 2003), and problems associated with wastewater holding ponds, such as potential facilitation of the spread of West Nile virus (Schrag and others 2011).

\section{SAGEBRUSH COMMUNITIES}

At first glance, sagebrush may appear to be homogenous (Figure 3); closer inspection has, however, revealed an intricate, species-rich mosaic of sagebrush taxa that are largely defined by climate and soil properties (Barker and McKell 1983; Mahalovich and McArthur 2004; Miglia and others 2007; Still and

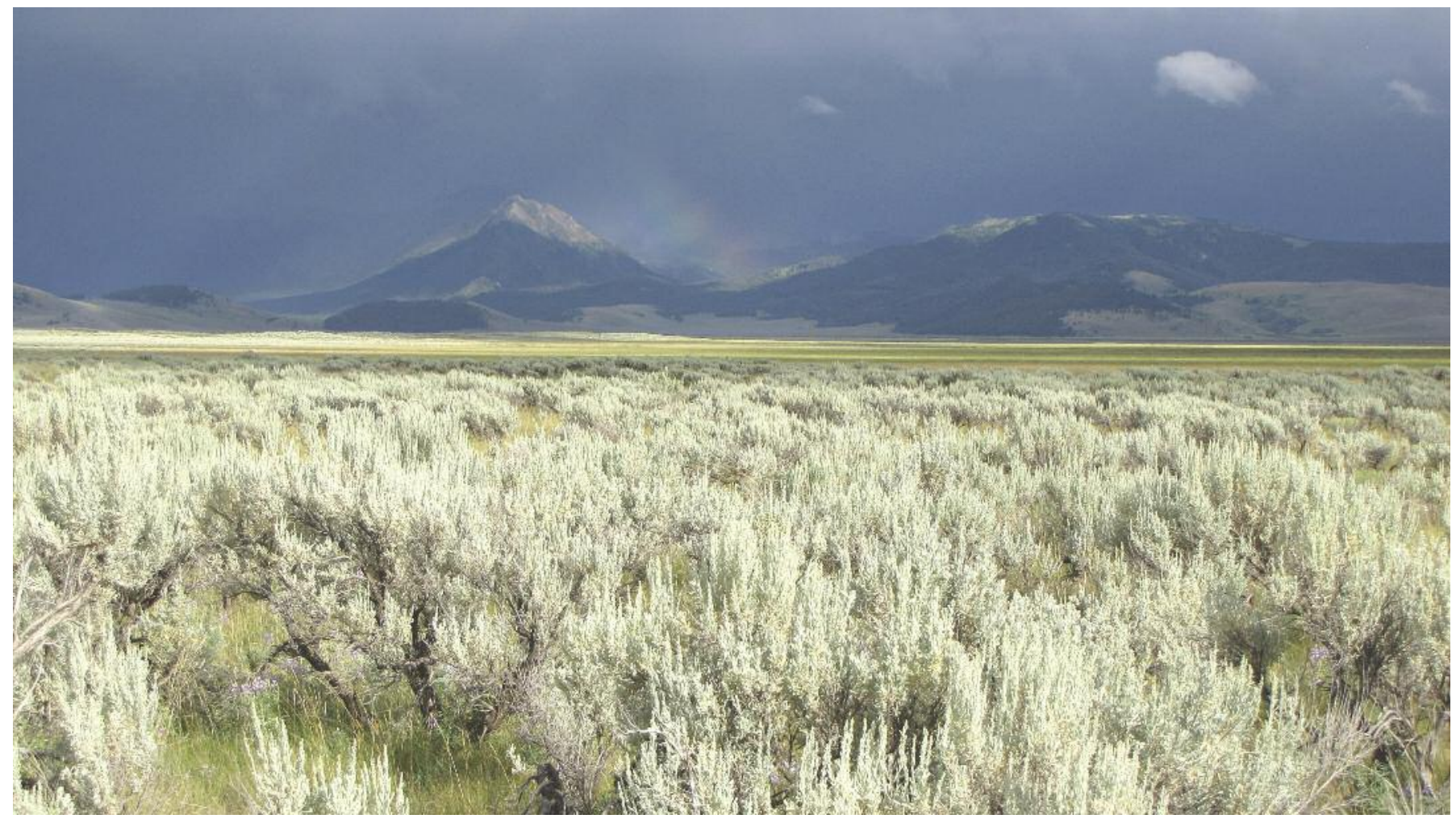

Figure 3. Artemisia tridentata ssp. tridentata in the Centennial Valley of southwestern Montana. Photo by Bebe Crouse, The Nature Conservancy 
Richardson 2015). Moreover, ecotones between these mosaics often harbor sagebrush derived from hybridization (McArthur and others 1988), some of which have been recognized by researchers as subspecies (Garrison and others 2013). These mosaics in turn foster various assemblages of flora and fauna referred to as communities that are critical to sustaining sage-grouse.

Classifying these taxa and characterizing the environments where they occur is a key activity and essential to successful restoration. The most predominant sagebrush species across the Great Basin, Wyoming Basin, and Colorado Plateau is A. tridentata (full nomenclature for most species discussed in this article is found in Tables 1-4). This species has, however, clearly diverged into subspecies that occupy specific niches (Mahalovich and McArthur 2004; Shultz 2006). Two subspecies, A. tridentata spp. tridentata (basin big sagebrush) and A. tridentata spp. wyomingensis (Wyoming big sagebrush), cooccur in basin habitats but are differentiated based primarily on soil depth (Barker and McKell 1983; McArthur and Sanderson 1999). With increasing elevation and precipitation these subspecies transition into subspecies A. tridentata spp. vaseyana (mountain big sagebrush). Genetic markers (Richardson and others 2012), growth rates (McArthur and Welch 1982), and phytochemicals (Stevens and McArthur 1974; Welch and McArthur 1981; Kelsey and others 1983; Wilt and others 1992) can be used to differentiate these 3 subspecies. In addition to these 3 widespread subspecies, 4 range-restricted subspecies (Table 2) occur across the Great Basin, Colorado Plateau, and southwestern US (Goodrich 2005). These subspecies have likely formed through hybridization with other subspecies or species similar to that proposed by Garrison and others (2013).

Dwarf sagebrush, A. arbuscula (includes 3 subspecies) and A. nova, are an important component to sagebrush communities (Goodrich 2005; Shultz 2006). These species are typically found in areas where soil and (or) climatic characteristics do not support $A$. tridentata (Rosentreter 2005). For example, $A$. nova can occupy ridgetops or rocky soils and form boundaries with A. tridentata ssp. wyomingensis. Artemisia nova can also form more continuous distributions, apparently driven by warmer and drier climates at lower elevations (Kitchen and McArthur 2007). Similarly, some subspecies of A. arbuscula occupy poorly drained claypan soils. Other sagebrush species have regional importance to mosaics and sage-grouse habitat. These include A. tripartita ssp. tripartita distributed across higher elevations that co-occur primarily with $A$. vaseyana, $A$. rigida distributed across basalt scablands in the Columbia Basin and Oregon, and A. cana ssp. cana found principally along the front range of the Rocky Mountains (Mahalovich and McArthur 2004; Rosentreter 2005). This robust mosaic of taxa is the foundation for sagebrush community floral diversity necessary for supporting sage-grouse. Biologists can use a pocket
Artemisia field guide (Shultz 2012) to help distinguish taxa and communities. While ample information and understanding of sagebrush taxonomy and niche specialization exists, developing the guidelines and methodologies to support a successful habitat restoration framework remains a major challenge.

\section{SAGEBRUSH HABITAT USE}

In general, GRSG use sagebrush habitat for courting, cover, and food based on sagebrush species composition and density. GRSG populations can remain resident in some areas, while other populations migrate between winter and breeding habitat or exhibit more complicated movements (Eng and Schladweiler 1972). Juvenile birds can use a wide range of habitats during autumn dispersal (Dunn and Braun 1986; Hannon and Martin 2006). Home range size varies from $125 \mathrm{~km}^{2}$ to $2764 \mathrm{~km}^{2}$ $(30,888$ ac to $683,000 \mathrm{ac}$ ) (Connelly and others 1988; Leonard and others 2000; Smith 2013). Leks occur where sagebrush cover is minimal $(<10 \%)$, such as open meadows, sparsely vegetated ridges, and even agricultural fields (Ellis and others 1989; Connelly and others 2004). Females can travel great distances from breeding leks to suitable nesting habitat (Braun and others 2005).

Although pre-laying hens use dwarf sagebrush communities for feeding (Figure 4), nesting occurs primarily in denser, tall sagebrush with tall native grass cover and proximity to abundant forbs (Connelly and others 2000; Thompson and others 2006; Hagen and others 2007; Ersch 2009). These sagebrush communities generally have canopy cover values that range from 12 to 43\% (Connelly and others 2000). Throughout the Wyoming Basin and Great Basin, GRSG tend to utilize sagebrush communities that include $A$. tridentata ssp. tridentata and $A$. cana in valleys, floodplains, and lower elevations and $A$. tridentata ssp. wyomingensis and A. tridentata ssp. vaseyana at mid to higher elevations. Artemisia rigida is also used for cover and nesting in central Washington. In the northern Great Basin, nesting success is associated with dense sagebrush cover with 10 to 50\% tall bunchgrass cover (Gregg and others 1994; Crawford and others 2004). While dwarf and tall sagebrush communities are most commonly used for nesting, other shrub communities in association with sagebrush can support nests, including those inhabited by Purshia tridentata Pursh DC (Rosaceae) and members of the Asteraceae (Ericameria, Chrysothamnus, Tetradymia canescens DC).

During late spring to early summer following hatch, broods move to more open sagebrush canopy cover to feed on insects and forbs. Not surprising, as canopy cover of big sagebrush decreases, the abundance of grasses and forbs increases (Olson and Whitson 2002) as does the abundance of invertebrates hosted by the herbaceous plants. Moreover, as discussed earlier, dwarf sagebrush (for example, A. arbuscula, A. nova, A. tripartita) inhabits soils less conducive to big sagebrush. 
TABLE 2

Artemisia conservation status, range, and community types.

\begin{tabular}{|c|c|c|c|c|}
\hline $\begin{array}{l}\text { Species } \\
\text { •According to Garcia and others (2011) }\end{array}$ & $\begin{array}{l}\text { Global } \\
\text { status }\end{array}$ & Range & Soils & Community ranks and types \\
\hline $\begin{array}{l}\text { Artemisia arbuscula Nutt. } \\
\text { ssp. arbuscula }\end{array}$ & G5 & $\begin{array}{l}\text { CA, ID, MT, NV, } \\
\text { OR, UT, WA, WY }\end{array}$ & $\begin{array}{l}\text { Rocky, calcareous clays } \\
\text { or silt loams }\end{array}$ & G2-G5 sage-steppe and grasslands \\
\hline $\begin{array}{l}\text { A. arbuscula ssp. longicaulis } \\
\text { Winwood \& McArthur }\end{array}$ & G4 & $\mathrm{CA}, \mathrm{NV}, \mathrm{OR}$ & Alluvial silts and sands & $\begin{array}{l}\text { Sage-steppe communities } \\
\text { on alluvial fans }\end{array}$ \\
\hline $\begin{array}{l}\text { A. arbuscula ssp. longiloba } \\
\text { (Osterh.) L.M. Shultz } \\
\text {-A. longiloba (Osterh.) Beetle }\end{array}$ & G4 & MT, WY & $\begin{array}{l}\text { Fine textured, shallow } \\
\text { clay or silt loams }\end{array}$ & $\begin{array}{l}\text { G3-G4 sage-steppe and } \\
\text { stream terraces }\end{array}$ \\
\hline $\begin{array}{l}\text { A. arbuscula ssp. thermopola } \\
\text { Beetle }\end{array}$ & G5T3Q & CA, ID, OR, UT, WY & $\begin{array}{l}\text { Well-drained to poorly } \\
\text { drained clay soils above } \\
\text { igneous or volcanic rock }\end{array}$ & G2 grasslands ID, WY \\
\hline A. bigelovii A. Gray & G5 & $\begin{array}{l}\mathrm{AZ}, \mathrm{CA}, \mathrm{CO}, \mathrm{NV} \\
\mathrm{NM}, \mathrm{TX}, \mathrm{UT}\end{array}$ & $\begin{array}{l}\text { Shallow sandy to clay } \\
\text { loams }\end{array}$ & $\begin{array}{l}\text { G3 warm and cool woodlands, } \\
\text { grasslands, desert rock vegetation, } \\
\text { rock outcrops }\end{array}$ \\
\hline $\begin{array}{l}\text { A. cana ssp. bolanderi } \\
\text { (A. Gray) G.H. Ward }\end{array}$ & G3G4? & $\mathrm{CA}, \mathrm{NV}, \mathrm{OR}$ & Gravelly loams & $\begin{array}{l}\text { G1-G3 streams and sage-steppes } \\
\text { mountain meadow }\end{array}$ \\
\hline $\begin{array}{l}\text { A. cana ssp. viscidula } \\
\text { (Osterh.) Beetle }\end{array}$ & G3G4? & $\begin{array}{l}\text { Canada: } \mathrm{AB}, \mathrm{MB} ; \\
\text { US: AZ, CO, ID, MT, } \\
\text { NV, NM, UT, WY }\end{array}$ & $\begin{array}{l}\text { Alluvial sandy loams } \\
\text { to loams }\end{array}$ & $\begin{array}{l}\text { G1-G5 wet meadows, streambanks, } \\
\text { floodplains, snow beds }\end{array}$ \\
\hline A. filifolia Torr. & G5 & $\begin{array}{l}\text { AZ, CO, KS, NE, NV, } \\
\text { NM, OK, SD, UT, WY }\end{array}$ & $\begin{array}{l}\text { Sandy or gravelly or } \\
\text { clay loams with clay or } \\
\text { caliche layers; biological } \\
\text { crusts in Colorado } \\
\text { Plateau }\end{array}$ & $\begin{array}{l}\text { G1-G3 communities in western } \\
\text { Great Plains } \\
\text { G4-G5 communities dry sandy } \\
\text { uplands washes and river } \\
\text { floodplain terraces }\end{array}$ \\
\hline A. nova A. Nelson & G5 & $\begin{array}{l}\text { CA, CO, ID, MT, NV, } \\
\text { NM, OR, UT, WY }\end{array}$ & $\begin{array}{l}\text { Shallow, gravelly, lithic, } \\
\text { calcic }\end{array}$ & $\begin{array}{l}\text { G1-G3 dry, rocky hills, open sage- } \\
\text { steppe } \\
\text { G4-G5 southern Great Basin and } \\
\text { southwest US }\end{array}$ \\
\hline A. papposa S.F. Blake \& Cronquist & G4 & ID, (NV), OR & $\begin{array}{l}\text { Sands, sandy loams, } \\
\text { sandy clays or poorly } \\
\text { drained clays }\end{array}$ & $\begin{array}{l}\text { G3/G4 sage-steppe and grasslands, } \\
1 \mathrm{G} 2 / \mathrm{G} 3 \text { riparian community }\end{array}$ \\
\hline A. pedatifida Nutt. & G4 & $\begin{array}{l}\text { ID, CO, southwest MT, } \\
\text { WY }\end{array}$ & $\begin{array}{l}\text { Sands, sandy loams, } \\
\text { sandy clays derived from } \\
\text { shales or sandstones or } \\
\text { clays from alluvium }\end{array}$ & $\begin{array}{l}\text { G2-G3 communities sage-steppe } \\
\text { grasslands }\end{array}$ \\
\hline A. porteri Cronquist & G2 & WY & $\begin{array}{l}\text { Barren, gravelly clays } \\
\text { to clay loams }\end{array}$ & G2 barren slopes \\
\hline A. pygmaea A. Gray & G3G4 & $\mathrm{AZ}, \mathrm{CO}, \mathrm{NV}, \mathrm{NM}, \mathrm{UT}$ & $\begin{array}{l}\text { Calcic, shale clays with } \\
\text { gravel content, gypsum } \\
\text { outcrops }\end{array}$ & $\begin{array}{l}\text { G2 communities in some states; } \\
\text { G3-G4 sage-steppe }\end{array}$ \\
\hline
\end{tabular}


Artemisia conservation status, range, and community types.

\begin{tabular}{|c|c|c|c|c|}
\hline $\begin{array}{l}\text { Species } \\
\text { •According to Garcia and others (2011) }\end{array}$ & $\begin{array}{l}\text { Global } \\
\text { status }\end{array}$ & Range & Soils & Community ranks and types \\
\hline A. rigida (Nutt.) A. Gray & G5 & ID, MT, OR, WA & $\begin{array}{l}\text { Stony, shallow rarely } \\
\text { with clay subsoils }\end{array}$ & $\begin{array}{l}\text { G2-G4 sage communities in dry } \\
\text { rocky scablands, volcanic plains }\end{array}$ \\
\hline A. rothrockii A. Gray & G3 & $\mathrm{CA}$ & $\begin{array}{l}\text { Clays to gravelly silt } \\
\text { loams to loamy sands; } \\
\text { often carbonate rich }\end{array}$ & G3 mountain meadows \\
\hline $\begin{array}{l}\text { A. tridentata Nutt. ssp. parishii } \\
\text { (A. Gray) H.M. Hall \& Clem. }\end{array}$ & G5T2T4 & $\begin{array}{l}\text { Central and southern } \\
\text { CA }\end{array}$ & Dry, sandy & $\begin{array}{l}\text { Desert, mountain, and coastal } \\
\text { grasslands and shrub communities } \\
\text { in valleys and foothills }\end{array}$ \\
\hline $\begin{array}{l}\text { A. tridentata Nutt. ssp. spiciformis } \\
\text { (Osterh.) Kartesz \& Gandhi } \\
\text {-A. spiciformis Osterh. }\end{array}$ & G5T3T4 & $\begin{array}{l}\mathrm{CA}, \mathrm{CO}, \mathrm{ID}, \mathrm{MT}, \mathrm{NV}, \\
\text { WA, WY }\end{array}$ & Shallow loams, rocky & $\begin{array}{l}\text { Subalpine, mountain sage-steppe } \\
\text { and grasslands }\end{array}$ \\
\hline $\begin{array}{l}\text { A. tridentata Nutt. ssp. tridentata } \\
\text {-A. tridentata ssp. tridentata } \\
\text { (Osterh.) Beetle }\end{array}$ & G5 & $\begin{array}{l}\text { Canada: } \mathrm{AB}, \mathrm{BC} \text {; US: } \\
\mathrm{AZ}, \mathrm{CA}, \mathrm{CO}, \mathrm{ID}, \mathrm{MT} \text {, } \\
\text { NE, NM, ND, OR, } \\
\text { SD, WA, WY }\end{array}$ & $\begin{array}{l}\text { Sandy to sandy loams, loess } \\
\text { soils }\end{array}$ & $\begin{array}{l}\text { G1-G5 warm to cool sage-steppe } \\
\text { and grasslands }\end{array}$ \\
\hline $\begin{array}{l}\text { A. tridentata Nutt. ssp. vaseyana } \\
\text { (Rydb.) Beetle }\end{array}$ & G4/G5 & $\begin{array}{l}\text { Canada: AB, BC; US: } \\
\text { CA, CO, ID, MT, NE, } \\
\text { NV, ND, OR, SD, UT, } \\
\text { WA, WY }\end{array}$ & Loamy soils & $\begin{array}{l}\text { G2-G4 cool sage-steppe, } \\
\text { grasslands, forests and } \\
\text { woodlands }\end{array}$ \\
\hline $\begin{array}{l}\text { A. tridentata Nutt. ssp. wyomingensis } \\
\text { Beetle \& A.M. Young }\end{array}$ & G5 & $\begin{array}{l}\text { CA, CO, ID, MT, NE, } \\
\text { NV, ND, OR, SD, } \\
\text { UT, WY }\end{array}$ & Loamy to clay soils & $\begin{array}{l}\text { G1-G5 (WY) cool dry, sage- } \\
\text { steppe, grasslands, forests and } \\
\text { woodlands, rock vegetation }\end{array}$ \\
\hline $\begin{array}{l}\text { A. tridentata Nutt. ssp. xericensis } \\
\text { Winward ex R. Rosentreter \& } \\
\text { R. Kelsey }\end{array}$ & G5T1T3 & ID & Deep alluvial soils & G1 sage-steppe \\
\hline $\begin{array}{l}\text { A. tridentata Nutt. ssp. } \\
\text { xbonnevillensis H. Garrison, } \\
\text { L. Schultz, \& E.D. McArthur }\end{array}$ & No rank & ID, UT & Sandy alluvial loams & $\begin{array}{l}\text { Sage-steppe on lakeshore } \\
\text { sediments }\end{array}$ \\
\hline $\begin{array}{l}\text { A. tripartita Rydb. ssp. rupicola } \\
\text { Beetle }\end{array}$ & G5T3 & $\mathrm{MT}, \mathrm{WY}$ & Coarse-textured soils & G3 grassland and sage-steppe \\
\hline A. tripartita Rydb. ssp. tripartita & G5T3T5 & $\begin{array}{l}\text { Canada: BC; US: CA, } \\
\text { ID, MT, NV, OR, } \\
\text { UT, WA, WY }\end{array}$ & $\begin{array}{l}\text { Sandy to gravelly soils, } \\
\text { loams, or loess over } \\
\text { bedrock }\end{array}$ & $\begin{array}{l}\text { G1-G3 grassland and } \\
\text { sage-steppe }\end{array}$ \\
\hline $\begin{array}{l}\text { A. tridentata Nutt. ssp. spiciformis } \\
\text { (Osterh.) Kartesz \& Gandhi } \\
\text { •A. spiciformis Osterh. }\end{array}$ & G5T3T4 & $\begin{array}{l}\mathrm{CA}, \mathrm{CO}, \mathrm{ID}, \mathrm{MT}, \mathrm{NV} \\
\text { WA, WY }\end{array}$ & Shallow loams, rocky & $\begin{array}{l}\text { Subalpine, mountain sage-steppe } \\
\text { and grasslands }\end{array}$ \\
\hline $\begin{array}{l}\text { A. tridentata Nutt. ssp. tridentata } \\
\text {-A. tridentata ssp. tridentata } \\
\text { (Osterh.) Beetle }\end{array}$ & G5 & $\begin{array}{l}\text { Canada: } \mathrm{AB}, \mathrm{BC} \text {; US: } \\
\text { AZ, CA, CO, ID, MT, } \\
\text { NE, NM, ND, OR, } \\
\text { SD, WA, WY }\end{array}$ & $\begin{array}{l}\text { Sandy to sandy loams, loess } \\
\text { soils }\end{array}$ & $\begin{array}{l}\text { G1-G5 warm to cool sage-steppe } \\
\text { and grasslands }\end{array}$ \\
\hline $\begin{array}{l}\text { A. tridentata Nutt. ssp. vaseyana } \\
\text { (Rydb.) Beetle }\end{array}$ & G4/G5 & $\begin{array}{l}\text { Canada: AB, BC; US: } \\
\text { CA, CO, ID, MT, NE, } \\
\text { NV, ND, OR, SD, UT, } \\
\text { WA, WY }\end{array}$ & Loamy soils & $\begin{array}{l}\text { G2-G4 cool sage-steppe, } \\
\text { grasslands, forests and } \\
\text { woodlands }\end{array}$ \\
\hline $\begin{array}{l}\text { A. tridentata Nutt. ssp. wyomingensis } \\
\text { Beetle \& A.M. Young }\end{array}$ & G5 & $\begin{array}{l}\mathrm{CA}, \mathrm{CO}, \mathrm{ID}, \mathrm{MT}, \mathrm{NE} \\
\mathrm{NV}, \mathrm{ND}, \mathrm{OR}, \mathrm{SD}, \\
\text { UT, WY }\end{array}$ & Loamy to clay soils & $\begin{array}{l}\text { G1-G5 (WY) cool dry, sage- } \\
\text { steppe, grasslands, forests and } \\
\text { woodlands, rock vegetation }\end{array}$ \\
\hline
\end{tabular}


Artemisia conservation status, range, and community types.

\begin{tabular}{|c|c|c|c|c|}
\hline $\begin{array}{l}\text { Species } \\
\text { •According to Garcia and others (2011) }\end{array}$ & $\begin{array}{l}\text { Global } \\
\text { status }\end{array}$ & Range & Soils & Community ranks and types \\
\hline $\begin{array}{l}\text { A. tridentata Nutt. ssp. xericensis } \\
\text { Winward ex R. Rosentreter \& } \\
\text { R. Kelsey }\end{array}$ & G5T1T3 & ID & Deep alluvial soils & G1 sage-steppe \\
\hline $\begin{array}{l}\text { A. tridentata Nutt. ssp. } \\
\text { xbonnevillensis H. Garrison, } \\
\text { L. Schultz, \& E.D. McArthur }\end{array}$ & No rank & ID, UT & Sandy alluvial loams & $\begin{array}{l}\text { Sage-steppe on lakeshore } \\
\text { sediments }\end{array}$ \\
\hline $\begin{array}{l}\text { A. tripartita Rydb. ssp. rupicola } \\
\text { Beetle }\end{array}$ & G5T3 & MT, WY & Coarse textured soils & G3 grassland and sage-steppe \\
\hline A. tripartita Rydb. ssp. tripartita & G5T3T5 & $\begin{array}{l}\text { Canada: BC; US: CA, } \\
\text { ID, MT, NV,OR, } \\
\text { UT, WA, WY }\end{array}$ & $\begin{array}{l}\text { Sandy to gravelly soils, } \\
\text { loams, or loess over } \\
\text { bedrock }\end{array}$ & $\begin{array}{l}\text { G1-G3 grassland and } \\
\text { sage-steppe }\end{array}$ \\
\hline
\end{tabular}

\section{Bud Sage and Chicken Sage}

\begin{tabular}{|c|c|c|c|c|}
\hline $\begin{array}{l}\text { Picrothamnus desertorum Nutt. } \\
\text {-Artemisia spinescens DC. Eaton }\end{array}$ & G5 & $\begin{array}{l}\text { AZ, CA, CO, MT, } \\
\text { NV, NM, OR, UT, WY }\end{array}$ & $\begin{array}{l}\text { Sands, sandy loams, } \\
\text { sandy clays eolian or } \\
\text { alluvium derived or } \\
\text { poorly drained clays } \\
\text { from alluvium }\end{array}$ & $\begin{array}{l}\text { G2/G3 (MT, WY) sage-steppe } \\
\text { and G3-G5 (NV, OR, UT, WY) }\end{array}$ \\
\hline $\begin{array}{l}\text { Sphaeromeria argentea Nutt. } \\
\bullet \text { A. argentea S. Garcia and others }\end{array}$ & G3G4 & $\mathrm{CO}, \mathrm{ID}, \mathrm{MT}, \mathrm{NV}, \mathrm{WY}$ & $\begin{array}{l}\text { Sands, silts, clays loams, } \\
\text { gravelly loams, often } \\
\text { calcareous, with cobble } \\
\text { or gravel }\end{array}$ & $\begin{array}{l}\text { G2 grassland communities in } \\
W Y, I D\end{array}$ \\
\hline $\begin{array}{l}\text { S. cana (D.C. Eaton) A. Heller } \\
\text {-A. albicans S. Garcia and others }\end{array}$ & G3/G4 & $C A, N V, O R$ & $\begin{array}{l}\text { Rocky crevices and talus } \\
\text { slopes }\end{array}$ & $\begin{array}{l}\text { Sparsely vegetated cliffs, } \\
\text { talus slopes }\end{array}$ \\
\hline $\begin{array}{l}\text { S. capitata Nutt. } \\
\text { - A. capitata (Nutt.) S. Garcia and } \\
\text { others }\end{array}$ & G3 & $\mathrm{CO}, \mathrm{MT}, \mathrm{UT}, \mathrm{WY}$ & $\begin{array}{l}\text { Shallow, rocky sometimes } \\
\text { calcareous soils }\end{array}$ & G3 dry, rocky hills, sage-steppe \\
\hline $\begin{array}{l}\text { S. compacta (H.M. Hall) } \\
\text { A.H. Holmgren, L.M. Shultz } \\
\text { \& Lowrey } \\
\text {-Artemisia constricta S. Garcia and oth }\end{array}$ & G2 & NV & Gravelly, limestone & $\begin{array}{l}\text { G2 coniferous woodlands, alpine } \\
\text { and rock, talus and scree }\end{array}$ \\
\hline $\begin{array}{l}\text { S. diversifolia (D.C. Eaton) Rydb. } \\
\bullet \text { A. inaequifolia S. Garcia and others }\end{array}$ & G3/G4 & NV, UT & $\begin{array}{l}\text { Shallow to moderately deep, } \\
\text { rocky soils, rock crevices } \\
\text { on limestone or quartzite }\end{array}$ & $\begin{array}{l}\text { Sparsely vegetated cliffs, } \\
\text { rocky slopes }\end{array}$ \\
\hline $\begin{array}{l}\text { S. potentilloides (A. Gray) A. Heller } \\
\text { var. nitrophila (Cronquist) A.H. } \\
\text { Holmgren, L.M. Shultz \& Lowrey }\end{array}$ & G5T4 & Snake River ID, NV & $\begin{array}{l}\text { Alkaline fine-textured soils } \\
\text { subjected to seasonal } \\
\text { flooding }\end{array}$ & Wet meadows, springs \\
\hline $\begin{array}{l}\text { S. potentilloides (A. Gray) Rydb. } \\
\text { var. potentilloides }\end{array}$ & G5TNR & CA, ID, NV, OR & $\begin{array}{l}\text { Non-alkaline fine-textured } \\
\text { soils }\end{array}$ & $\begin{array}{l}\text { G2 mountain wet meadows, } \\
\text { hot springs, seeps }\end{array}$ \\
\hline $\begin{array}{l}\text { S. ruthiae A.H. Holmgren, L.M. } \\
\text { Shultz \& Lowrey } \\
\text {-A. ruthiae (A.H. Holmgren, L.M. } \\
\text { Shultz \& Lowrey) S. Garcia and othe }\end{array}$ & G2 & UT & $\begin{array}{l}\text { Sandstone, cliffs, boulder } \\
\text { talus and scree }\end{array}$ & $\begin{array}{l}\text { G2 woodlands, chaparral, rock, } \\
\text { talus scree sandstone crevice } \\
\text { woodland communities }\end{array}$ \\
\hline $\begin{array}{l}\text { S. simplex (A. Nelson) A. Heller } \\
\text {-A. simplex (A. Nelson) S. Garcia } \\
\text { and others }\end{array}$ & G2 & WY & Rocky limestone soils & G2 cushion communities \\
\hline
\end{tabular}

Notes: Conservation rankings: G1 = highly imperiled; G2 = imperiled; G3 = vulnerable; G4 = apparently secure; G5 = secure (NatureServe 2014). 


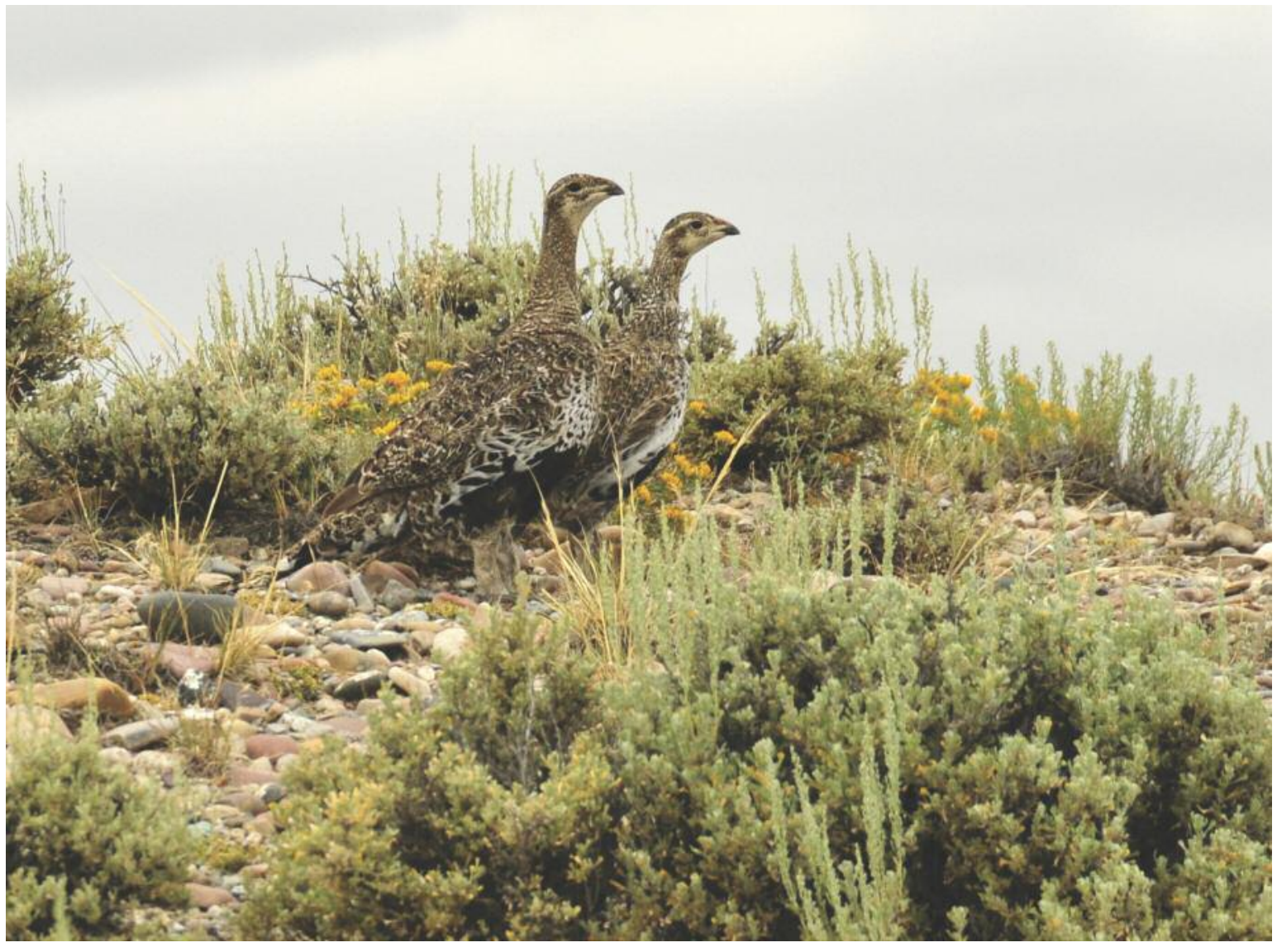

Figure 4. Female Greater Sage-Grouse on the Seeskadee National Wildlife Refuge, Sweetwater County, Wyoming. Photo by Tom Koerner, US Fish \& Wildlife Service

As summarized by Arkle and others (2014), in the Great Basin, GRSG occur more frequently on sites where big and dwarf sagebrush intergrade, perhaps because of the cover advantages of the tall shrubs and because the dwarf sagebrush species provide a more metabolically efficient forage for GRSG. Low elevation sagebrush communities are used for brood rearing and are preferred for forage (Connelly and others 2013). Subshrub sagebrush species, such as $A$. frigida and A. pedatifida, and herbaceous species, such as $A$. ludoviciana and related genera such as Tanacetum nuttallii Torr. \& A. Gray (Asteraceae), are consumed by juvenile and adult GRSG. Other woody Artemisia, such as A. filifolia, of the west-central Great Plains and Southwest historically provided habitat, and A. cana of the northern Great Plains and Great Basin, provides habitat in association with major rivers.

During winter, the diet of GRSG is exclusively sagebrush (Wallestad and others 1975) and winter habitat may be the most limited because, in addition to the forage quality of different sagebrush species, topographical and stand structure features are critical (Eng and Schladweiler 1972; Remington and Braun 1985). When winter precipitation is high, birds may travel greater distances to find sagebrush blown free of snow.
Low elevation sagebrush communities are often used as winter habitat (Connelly and others 2013).

\section{GREATER SAGE-GROUSE DIET}

Life history and diet of GRSG are closely tied to the phenological development of sagebrush habitats. Brood rearing and chick productivity are highly dependent on sagebrush communities that contain a diversity and abundance of forbs and insects necessary for early GRSG development. Physiological condition of pre-laying hens may also contribute to juvenile survival and is highly dependent on understory flora from early spring to midsummer, as well as during the first few weeks post-hatch for young broods.

Barnett and Crawford (1994) found that forbs comprised 18 to $50 \%$ (by weight) of the diet of pre-nesting hens; consumption of forbs containing high calcium, crude protein, and phosphorus content can improve reproductive success. Hens are known to feed on a variety of early spring annuals and perennials including the flower buds of Ranunculus and Lomatium. Chicks have been documented to consume 41 families of invertebrates and 34 genera of forbs (Drut and others 1994b); 
however, some plant taxa are preferred. Gregg and Crawford (2009) found that Lepidoptera availability and the annual Microsteris gracilis frequency were the only habitat variables related to brood survival, decreasing risk of total brood loss by nearly $12 \%$ and $3 \%$, respectively (Figure 5 ).

Chicks less than 3 wk old need adequate quantities of insects for survival and development, whereas chicks greater than $3 \mathrm{wk}$ old require insects for optimum growth (Johnson and Boyce 1990). Klebenow and Gray (1968) and Peterson (1970) found that invertebrates comprised 52 to $60 \%$ of the diet of chicks less than $7 \mathrm{~d}$ old, whereas forbs were the major component of chick diets 2 to 10 wk post-hatch. Greater forb and insect consumption has been positively correlated to chick survival (Barnett and Crawford 1994; Drut and others 1994a,b; Thompson and others 2006).

In Oregon, during the first week post-hatch (May to June), chicks consume ants (Hymenoptera: Formicidae), darkling beetles (Coleoptera: Tenebrionidae), scarab beetles (Coleoptera: Scarabaeidae), and various caterpillars (Lepidoptera) (Ersch 2009). Noteworthy, Ericameria and Chrysothamnus (rabbitbrush) communities contained more caterpillars throughout May and June than $\operatorname{did} A$. tridentata ssp. vaseyana communities (Ersch 2009), providing optimal food sources during early brood rearing. Many other invertebrate taxa are consumed by chicks in other regions of the Great Basin and Wyoming Basin and Great Plains (Wallestad and others 1975; Thompson and others 2006).

Early spring emerging forbs are especially important for pre-laying hens and chicks during their first $3 \mathrm{wk}$ of development. Research revealed that forbs comprised $50 \%$ or more of the juvenile and adult summer diets in Utah, Idaho, Montana, and Oregon (Trueblood 1954; Klebenow and Gray 1968; Wallestad and others 1975; Barnett 1992; Barnett and Crawford

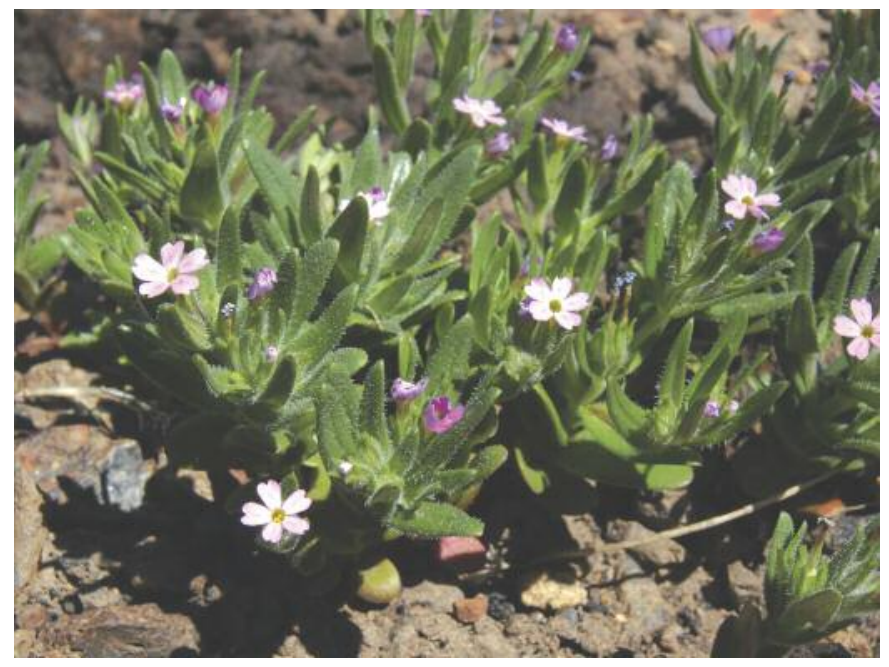

Figure 5. Microsteris gracilis is an important annual in chick survival of Greater Sage-Grouse. Photo by Jim Morefield
1994; Connelly and others 2000; Gregg and others 2008; Ersch 2009). In particular, Lomatium species (Figure 6) are preferred forage by pre-laying hens and chicks in the Columbia Basin and Great Basin, comprising a significant portion of their diet (Barnett 1992; Barnett and Crawford 1994; Ersch 2009). Important forbs, including annuals, consumed by adults and chicks (for their first $10 \mathrm{wk}$ ) are listed in Table 3.

The suite of plants consumed reflects species availability as summer progresses and includes native species in natural communities, forage crops in agricultural fields, and weeds in disturbed sagebrush communities (Klebenow and Gray 1968). Where sagebrush has been removed, grazed, or burned, crops and weeds commonly occur (Prevéy and others 2010a,b) and have been found to be major dietary components (Wallestad and others 1975; Barnett 1992; Barnett and Crawford 1994). Throughout the late summer and fall, juveniles continue feeding on available forbs, such as Eriogonum (Braun and others 2005) in a variety of upland habitats, succulent forbs in riparian areas, as well as leaves and flower buds of sagebrush. GRSG

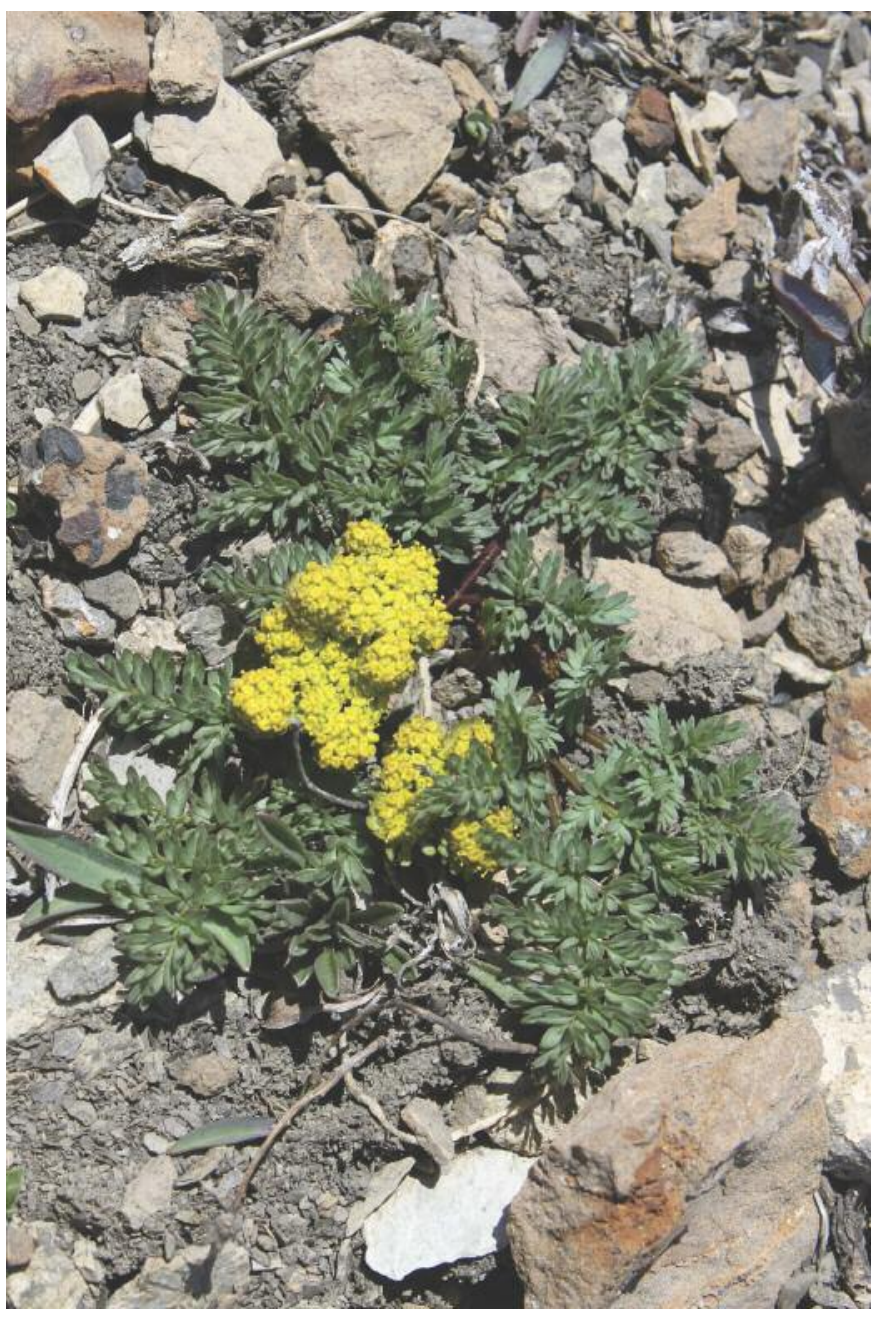

Figure 6. The lomatiums, including Lomatium cous (S. Watson) J.M. Coult. \& Rose, are a valuable contributor to the diet of Greater Sage-Grouse. Photo by Tara Luna 
TABLE 3

Native forb species documented to be in the diet of Greater Sage-Grouse. ${ }^{z}$

\begin{tabular}{|c|c|c|c|}
\hline Species & Sourcey & Species & Source $y$ \\
\hline Achillea L. Asteraceae & 2 & Eriogonum Michx. Polygonaceae & 6,8 \\
\hline A. millefolium $\mathrm{L}$. & $1,3,4,5,8$ & 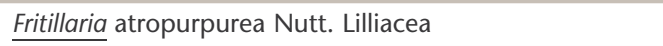 & 5 \\
\hline A. glauca (Pursh) Raf. & 5 & Geum L. Rosaceae & 2 \\
\hline A. grandiflora (Nutt.) Greene & 5 & Grindelia squarrosa (Pursh) Dunal Asteraceae & 3,4 \\
\hline A. dimorpha (Nutt.) Torr. \& A. Gray & 8 & $\underline{\text { Lepidium densiflorum Schrad. }}$ & 3 \\
\hline A. microphylla Rydb. & 5 & Leptosiphon harknessiiv (Curran) J.M. Porter \& & 1 \\
\hline Arabis L. Brassicaceae & 6 & L.A. Johnson Polemoniaceae & \\
\hline Arenaria L. Caryophyllaceae & 5,7 & Lomatium Raf. Apiaceae & $6,7,8$ \\
\hline A. lentiginosus Douglas ex Hook. & 5 & Mertensia Roth Boraginaceae & 6 \\
\hline A. obscurus S. Watson & $5,6,8$ & Microseris D. Don Asteraceae & 8 \\
\hline A. purshii Douglas ex Hook. & $5,6,8$ & Microsteris gracilis (Hook) Greene Polemoniaceae & $5,7,8$ \\
\hline Balsamorhiza Nutt. Asteraceae & 8 & M. gracilis (Hook.) Greene var. gracilisu & 8 \\
\hline Blepharipappus scaber Hook. Asteraceae & 7 & Mimulus L. Scrophulariaceae & 8 \\
\hline Calochortus macrocarpus Douglas & 1 & M. nanus Hook. \& Arn. & 5 \\
\hline Castilleja angustifolia (Nutt.) G. Don Scrophulariaceaex & 1 & Monolepis nuttalliana (Schult.) Greene Chenopodiaceae & 1 \\
\hline Cleome platycarpa Torr. Capparaceae & 5 & Orobanche L. Orobanchaceae & 7,8 \\
\hline Collinsia Nutt. Scrophulariaceae ${ }^{x}$ & 6 & 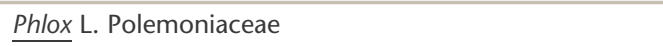 & 6,7 \\
\hline Epilobium L. Onagraceae & 5 & T. cyathiferum Lindl. & 5 \\
\hline Erigeron L. Asteraceae & $2,7,8$ & T. gymnocarpon Nutt. & 5 \\
\hline E. corymbosus Nutt. & 5 & T. macrocephalum (Pursh) Poir. & 8 \\
\hline E. lonchophyllus Hook. & 5 & Vicia americana Muhl. ex Willd. Fabaceae & 3 \\
\hline
\end{tabular}

Notes: Underlined genera are consumed by chicks during their first 14 wk of development. Bold genera include annual plants.

z Determined from analysis of GRSG crops; most likely this is partial list. For example, in their results, Drut and others (1994) stated that they observed GRSG consuming 34 genera of forbs, yet named only 11. In addition, most authors referenced here identified plants only to the genus. Note this list does not account for GRSG preference; some of these species are consumed in large amounts, others rarely. Consult the original sources for more information on GRSG feeding preferences. Chick diet information from sources 1, 3, 5, 7, and fide 8.

y Sources: 1 = Klebenow and Gray (1968); 2 = Martin (1970); 3 = Peterson (1970); 4 = Wallestad and others (1975); 5 = Pyle (1992); $6=$ Barnett and Crawford (1994); 7 = Drut and others (1994b); 8 = Gregg (2006).

x ITIS (2015) places Castilleja in the Orobanchaceae and Collinsia in the Plantaginaceae.

w Formerly Lactuca pulchella.

$\checkmark$ Formerly Linanthus harknessii.

u Formerly Phlox gracilis.

t Formerly Aster.

s Formerly Aster occidentalis. 
feed exclusively on sagebrush during winter months (Wallestad and others 1975).

\section{RESTORATION TO SUPPORT GREATER SAGE-GROUSE}

Given the limited resources of management agencies, it is imperative to develop restoration strategies that yield the best success for establishing and retaining resilient sagebrush communities to support GRSG and other sagebrush-obligate species. The Great Basin Native Plant Project (GBNPP), a joint project of the USDI Bureau of Land Management (BLM) and the USDA Forest Service (USFS), is one of the primary research and development projects promoting the development of diverse native plant materials for restoration of the GRSG (Shaw and others 2012). GBNPP currently has more than 30 cooperating partners made up of universities, state and federal land management and research agencies, NGOs, private landowners, and seed producers. GBNPP continues to work with managers and botanists at BLM, USFS, and US Fish \& Wildlife Service to strategically develop plant materials that are known to be important components of GRSG habitat. Past research results, information to assist land managers, and current work can be viewed at the GBNPP website (http://www.GreatBasinNPP.org). In addition, ongoing research by the USFS Rocky Mountain Research Station (RMRS) focuses on sagebrush genetics, seed transfer guidelines, native plant development, restoration methods, habitat loss, modeling, and monitoring (see Finch and others 2015 for a concise review). While the scientific literature concerning sagebrush restoration is rich (for example, Arkle and others 2014; Chambers and others 2014), sources of a more applied nature, such as the Sagebrush Steppe Treatment Evaluation Project (SageSTEP; http://www.sagestep.org) and the Sagegrouse Habitat Assessment Framework (Stiver and others 2015) provide a wealth of pragmatic restoration information. Within the scope of this paper, we will narrow the discussion to 1) using proper sagebrush seed sources now and in the future, 2) developing and outplanting forbs, and 3) control of invasive grasses and forbs to ensure restoration success.

\section{Outplanting the Correct Sagebrush in the Correct Location}

Given that sagebrush is the foundation species in GRSG habitat, and that its absence from the landscape allows the populations of invasive plants to increase and native forbs and grasses to decrease (Prevéy and others 2010a,b), returning sagebrush to the landscape is imperative. Unfortunately, for sagebrush restoration, we may be failing to meet the mantra: the right seed in the right place at the right time. In the sagebrush steppe, disturbances and invasion by weeds are most prevalent in the driest and warmest areas (Chambers and oth- wyomingensis) is appropriate for many sagebrush restoration projects, and populations more local to the restoration site have higher first-year survival than more distant sources (Brabec and others 2015).

To obtain the sagebrush seed needed for restoration, land management agencies rely on private seed collectors and vendors. In high fire years, land management agencies may request in excess of $226,800 \mathrm{~kg}(500,000 \mathrm{lb})$ of sagebrush seeds (Krabacher 2015). Despite wyomingensis and A. tridentata ssp. tridentata (hereafter tridentata) growing in close proximity, these subspecies have vastly different moisture requirements and growth rates: tridentata prefers deeper soils or areas that retain winter moisture longer into the summer along dry washes and roadside ditches (Barker and McKell 1983; McArthur and others 1988) whereas wyomingensis favors shallower, drier soils in uplands and plateaus. The implication is clear: seeding misidentified tridentata on the wrong (that is, wyomingensis) site has the potential to reduce restoration success. In a recent study, Richardson and others (2015) found that wyomingensis had significantly greater seed weight than tridentata regardless of environment. Using this data, they determined that $83 \%$ of the certified seedlots labeled as wyomingensis collected in 2013 and 2014 and purchased by the BLM were largely composed of tridentata. Thus, we encourage seed collectors and land managers to use seed weight as a screening technique to ensure "the right seed for the right place."

In the future, sagebrush restoration planning will have to account for the impacts of climate change to maximize successful outcomes. It is clear from research that plant communities, taxa, and populations are in flux (Menzel and others 2006; Hackett and others 2008). Overall, the desert biomes of western North America are expected to expand $25 \%$ by mid-century. This expansion is, however, largely gained by warm deserts (that is, Mojave and Chihuahuan) at the expense of the sagebrush steppe (Rehfeldt and others 2012). Bioclimatic niche modeling of wyomingensis supports these findings. The climate niche of wyomingensis predicts a reduction of $39 \%$ by midcentury (Still and Richardson 2015) (Figure 7). Losses mainly occur in the trailing edge of subspecies distribution, which are associated with aridity; recent ecohydrological models for decade 2070 found that winter and spring precipitation will not support big sagebrush at its trailing edge (Schlaepfer and others 2015). The contracting areas of wyomingensis (Figure 7) are in the same areas where Mojave Desert climates are predicted to expand (Rehfeldt and others 2012). Moreover, contracting areas should not be viewed as hopeless for wyomingensis restoration, but they are more likely to be less resilient over the next few decades.

\section{Developing and Outplanting Forbs and Grasses}

The recovery of healthy GRSG populations will require the restoration of diverse sagebrush-associated native plant 


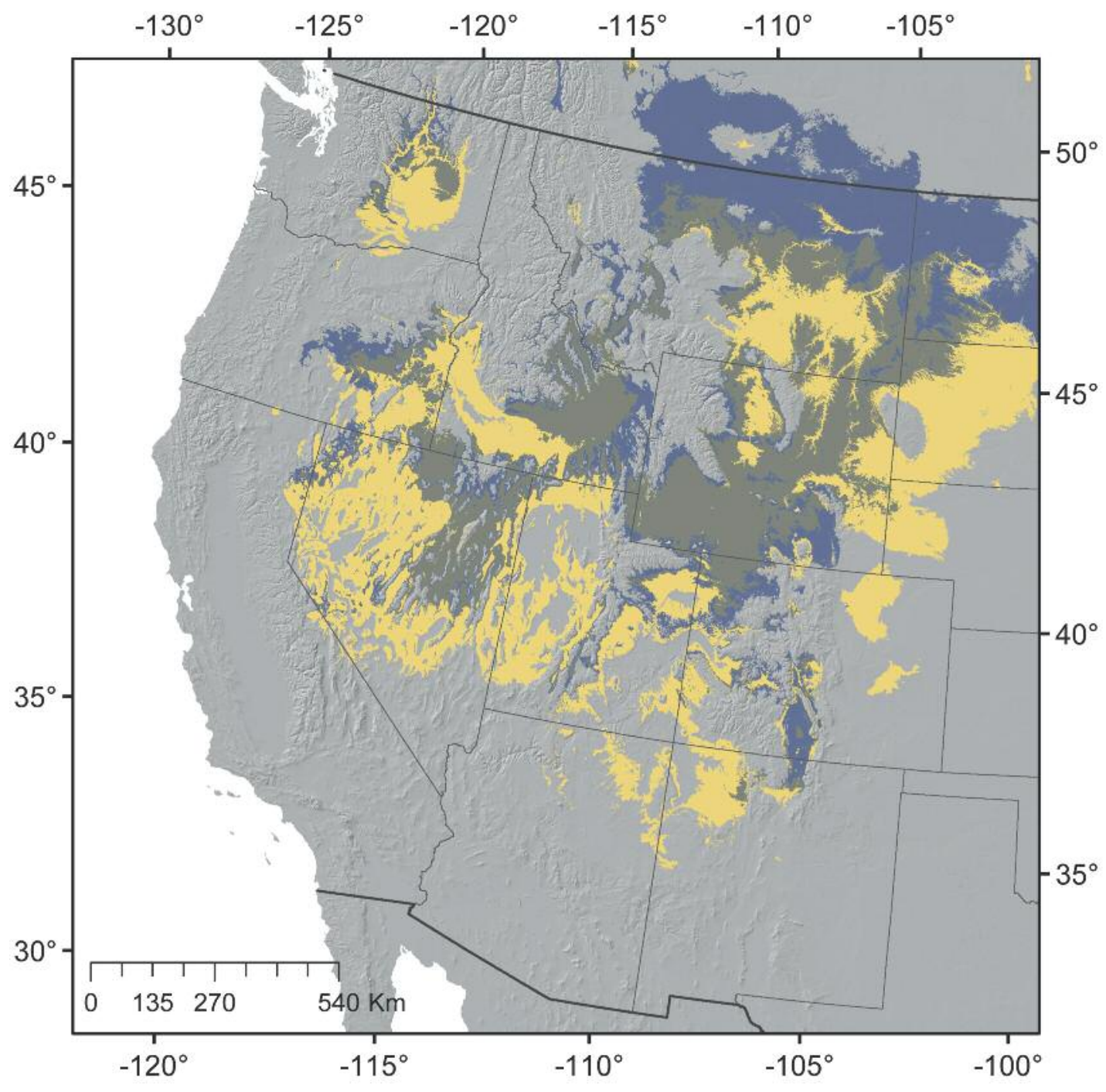

Figure 7. Artemisia tridentata ssp. wyomingensis climatic niche from present to decade 2050 (adapted from Still and Richardson 2015). Contracting niche space $=$ yellow, stable $=$ dark gray, and expanding $=$ blue. Projections for 2050 are based on representative concentration pathway 6.0 of the IPCC 5th assessment report.

communities. Restoration success can hinge on selecting plant materials that "match" conditions at degraded sites (Lesica and Allendorf 1999; Hufford and Mazer 2003), and the National Seed Strategy calls for using the "right seed in the right place at the right time" (PCA 2015). Plant species exhibit intraspecific, or ecotypic, adaptive variation across multiple spatial scales, from local to regional (Linhart and Grant 1996), which needs to be taken into account in seed source selection and plant material development (McKay and others 2005). The strength, spatial scale, and trait by environment correlations that define intraspecific adaptive variation can vary substantially by species and ecosystem (Linhart and Grant 1996; McKay and others 2005). Seed zones and seed transfer guidelines are management tools, developed originally in forestry, that are currently being used to define acceptable distances to transplant germplasm that preserve ecological and evolutionary relation- ships (Campbell 1991; Ying and Yanchuk 2006; Kilkenny 2015). Species-specific seed zones, also called empirical seed zones, are constructed by modeling the relationship between plant phenotypic traits, determined through common-garden studies, and climatic variables (St Clair and others 2013; Kilkenny 2015).

The 2 primary forms of common-garden studies include genecological studies, where many populations (often $>100$ ) are tested in one or a few common gardens, and reciprocal transplant studies, which test populations across multiple environments and usually use only a few populations (but see Wang and others 2010). Genecological studies are best suited to characterize adaptive genetic variation across a large proportion of a species' range and are therefore most often used for costeffective seed zone construction, while reciprocal transplant studies are best suited for fully characterizing the adaptivity 
and plasticity of specific plant materials across a range of environments (Kilkenny 2015). Data from all common-garden studies can be leveraged for use in more traditional agronomic methods of plant material selection, as well as to predict the effects of changing climates on plant populations of conservation concern (Kilkenny 2015). Plant material selection may include breeding or selection for specific traits, such as enhanced ability to establish under harsh conditions (for example, Jones and others 2009; Leger and Baughman 2015) or to compete with invasive species (for example, Leger 2008) or to just simply increase wild collections (Johnson and others 2010).

These studies are robust in the information they provide, but they require appreciable funding and time to accomplish. Despite this disadvantage, many species important to the sagebrush biome, and therefore, GRSG, have been evaluated and seed zones are now available, including grasses (for example, Pseudoroegneria spicata; St Clair and others 2013) and forbs (for example, Allium acuminatum Hool.; Johnson and others 2013). Until empirical seed zones can be developed for the full suite of grasses and forbs used by GRSG, provisional seed zones can be used to guide germplasm movement (Bower and others 2014).

With knowledge about where the plant species occurs and where seed sources can be moved, plant material production can proceed. Given that GRSG use a variety of forb species throughout the year, and their use also varies by season, it is important that species mixtures used in restoration activities be robust in their compliment of forb species-mixtures that include only a few forb species will not support the dietary needs of GRSG. Currently available materials, however, are unlikely to be adequate (in quantity and diversity) to restore sufficient sagebrush habitats for GRSG. Indeed, habitat models indicate that sage-grouse need highly diverse plant communities to thrive, and current seeding practices have fallen well short of that goal (Arkle and others 2014). Failure to meet the goal is in part because some forbs are just difficult to produce economically in quantities that allow for abundant use in projects. Notable problems include seed dormancy, indeterminate seed ripening, low stature that makes mechanical harvesting difficult, long durations between initial seed sowing and first seed harvest, and other factors (Shaw and others 2005; Meyer 2006; Boyer 2008). Thus, typical seed mixtures for sage-grouse restoration work often have limited numbers of species despite, for example, data from Wyoming documenting at least 10 genera of native forbs growing on quality GRSG habitat (Jacobs and others 2013). For example, Lambert (2005), discussing restoration of big sagebrush habitat (not specifically sagegrouse restoration), provides "generic" mixtures; these averaged 2, 6, and 4 species of shrubs (one being sagebrush), forbs, and grasses, respectively. A recommendation from North Dakota specifies 1 sagebrush species and 5 species each of forbs and grasses (USDA NRCS 2007). And, recommendations from bunchgrasses, rhizomatous grass, and shrubs, respectively (UGRB 2015). Thus, it is important that more economical methods for producing forbs are developed for commercial seed and nursery production. Not surprisingly, the recently released National Seed Strategy specifically discusses the need for additional research to develop species-specific methods for improved production (seeds and plants) of native species for restoration (PCA 2015).

A good starting point for working with native forbs is their life histories. Many native forbs important to GRSG initiate germination at temperatures at or barely above freezing, coinciding with cold to cool spring soil temperatures. Many early cold to cool temperature-requiring forbs adapted to soil moisture limitations possess thickened taproots or vertical fleshy root systems that can potentially reach greater root depth and efficiently utilize available soil moisture earlier and deeper in the soil profile and effectively compete for space and soil moisture with invasive annual grasses. For example, Parkinson and others (2013) found that early emerging and senescing forbs with vertical taproots, such as Lomatium macrocarpum (Nutt. ex Torr. \& A. Gray) J.M. Coult. \& Rose, and rapidly growing species, such as Sphaeralcea munroana (Douglas ex Lindl.) Spach ex Gray, showed no reduction in relative growth rate when grown with native grasses and exhibited the least reduction in relative growth rate when grown with cheatgrass.

Lomatium species, as a group, are early spring emergers, germinate at cold temperatures, and possess deep, storage taproots. Common and endemic Great Basin and Colorado Plateau spring and summer flowering Fabaceae (Astragalus, Lupinus, Trifolium), Eriogonum, and many Asteraceae provide important forage during later stages of juvenile development. Many of these same plants also possess deep taproots and occur in a wide range of Basin and Plateau sagebrush communities. Penstemon species (Figure 8) frequently found in sagebrush communities often possess woody caudexes surmounting fleshy branched roots, and these species may be more successfully established on moderately invaded sites. In addition to GRSG, they are important for supporting bees and migratory hummingbirds (Trochilidae). Balsamorhiza sagittata with its large caudex provides tall cover in association with sagebrush.

Propagation and native seed production protocols are available for many Great Basin, Wyoming Basin, and Colorado Plateau perennial forb species (Dunne and Dunne 2002; Archibald 2006; NPN 2015) and native bunchgrasses (Archibald and others 2000; Smith and Whalley 2002; NPN 2015). Researchers are gaining an understanding of critical seed germination temperatures for these forbs; Lomatium, Phlox, and some Eriogonum, adapted to late winter germination, germinate at cold temperatures of 3 to $6{ }^{\circ} \mathrm{C}\left(37\right.$ to $\left.42^{\circ} \mathrm{F}\right)$, while many basin Castilleja, Penstemon, and Trifolium species germinate at cool temperatures $\left(15^{\circ} \mathrm{C}\left[60^{\circ} \mathrm{F}\right]\right.$ or below). Asteraceae species, such as Agoseris, Antennaria, Erigeron, and 


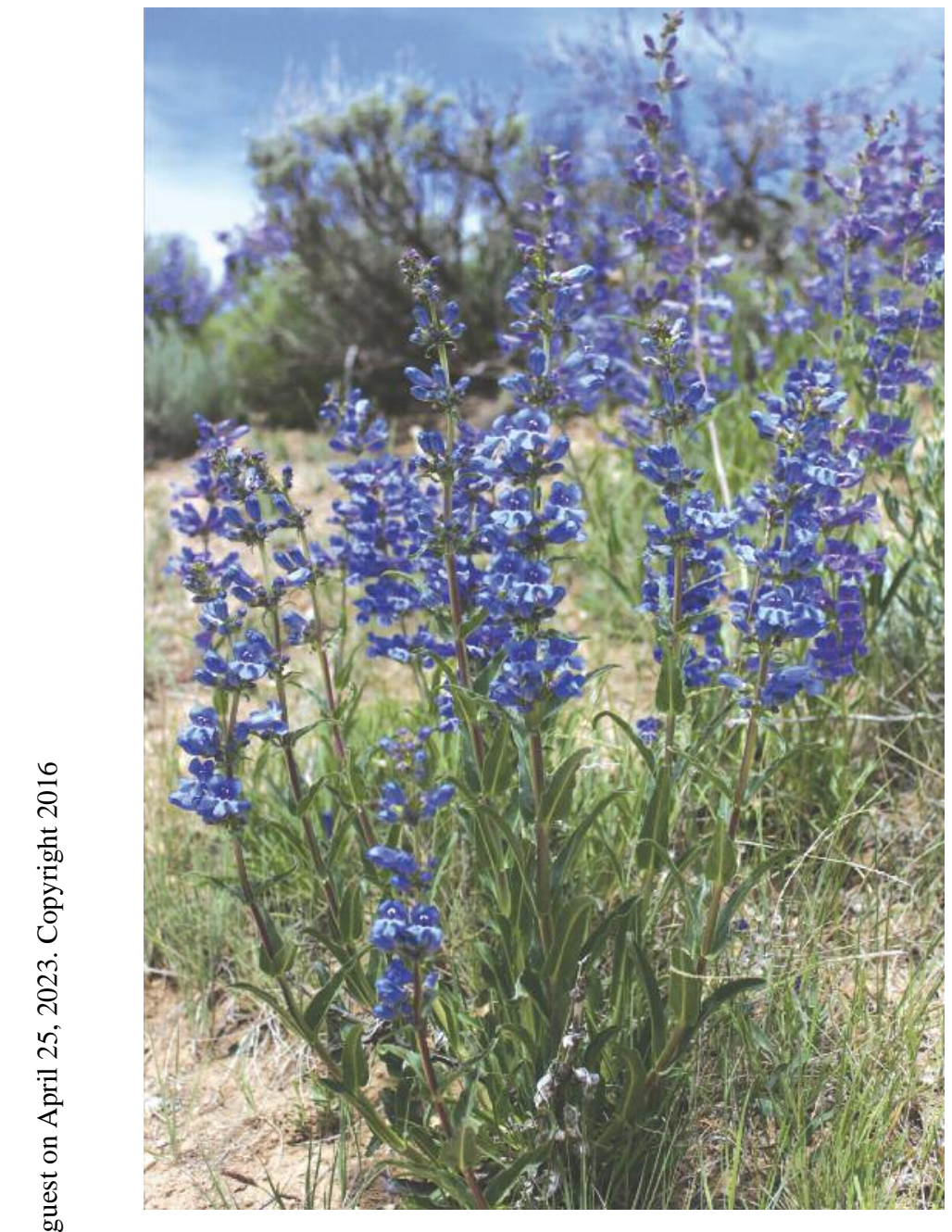

Figure 8. Penstemon radicosus A. Nelson growing with Artemisia tridentata ssp. tridentata in southwest Montana. Photo by Tara Luna
Crepis (Figure 9), as well as Astragalus, Lupinus, and some Castilleja and Penstemon species germinate at $20^{\circ} \mathrm{C}\left(68^{\circ} \mathrm{F}\right)$ (Baskin and Baskin 1998; Luna 2005). Some species have specific germination-enhancing requirements; Balsamorhiza sagittata, for example, germinates better when exposed to ethylene before stratification (Chambers and others 2006). And some genera, such as Eriogonum have species that germinate under a wide range of temperatures and during an extended period of several weeks (Meyer and Paulsen 2000).

Protocols for growing native forbs in seed production fields continue to improve (for example, Shock and others 2015). The same can be said for other shrub species important to the biome (for example, Ericameria nauseosa (Pall. ex Purch) G.L. Neson \& Baird; Love and others 2014a,b). Techniques for longterm storage of sagebrush seeds have been developed (Karrfalt and Shaw 2013), and techniques for growing (Long and Trimmer 2004; Fleege 2010), storing (Overton and others 2013), and outplanting (Davis and others forthcoming) sagebrush nursery stock are helping ensure successful restoration. For producing seedlings of strongly tap-rooted species (for example, Lomatium, Balsamorhiza) for which it is difficult to grow a "firm plug" for outplanting, rhizomes grown in bareroot beds (Landis 2008) or "soft-walled" container seedlings grown using Jiffy pellets or stabilized media that maintain a root plug regardless of root architecture (Woodruff and others 2014; Landis and Dumroese 2015) are worthy options to consider.

From 2001 through 2014, the GBNPP program evaluated 92 genera and 225 taxa of native plants (Table 4), of which about $80 \%$ are forbs. The number of annual forbs studied by GBNPP is only about $15 \%$ of all taxa (Table 4 ). More use of annual native forbs may have benefit. In addition to annual forbs being an important part (up to $45 \%$ ) of the diet of GRSG chicks less
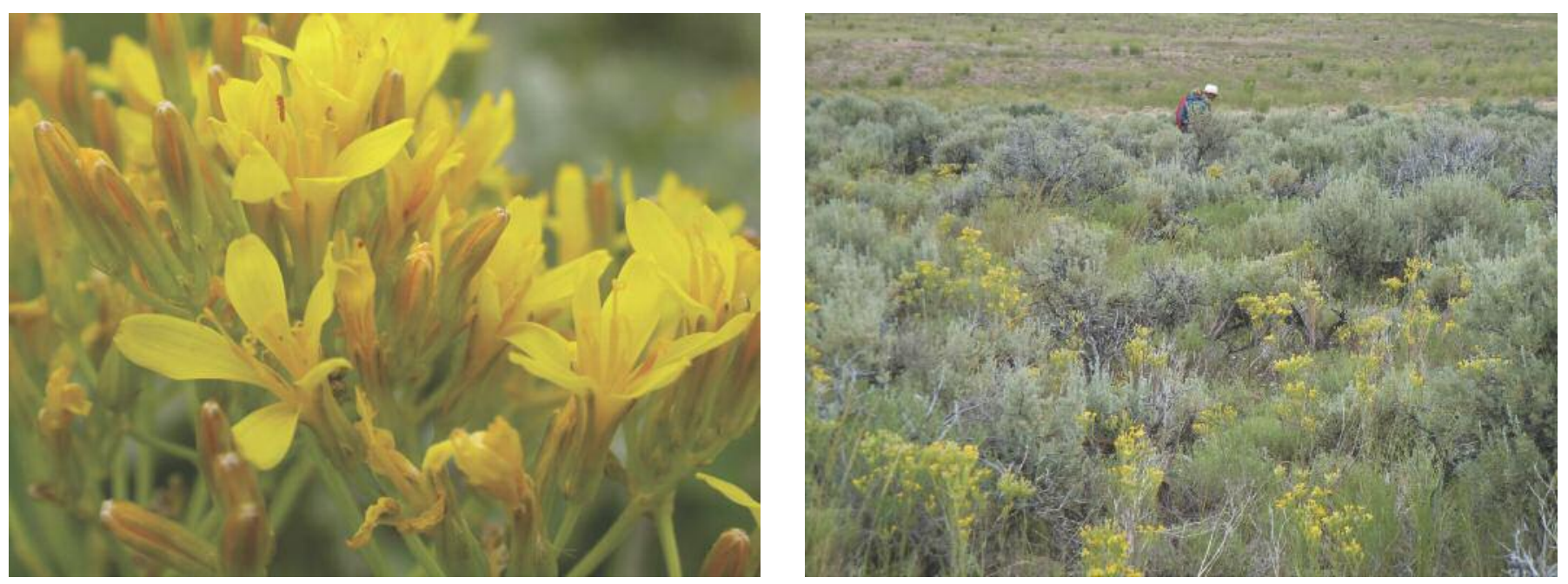

Figure 9. Crepis acuminata flowers (left) and growing within Artemisia tridentata ssp. wyomingensis (right) in Bingham County, Idaho. Photos by Matt Lavin 
TABLE 4

Genera of native shrubs (S), forbs (F; genera with annuals in bold), and perennial grasses (G) and the number of taxa (species and subspecies) under evaluation through the Great Basin Native Plant Project from 2001 through 2014.

\begin{tabular}{|c|c|c|c|c|c|}
\hline Genus & Taxa & Type & Genus & Taxa & Type \\
\hline Achnatherum P. Beauv. Poaceae & 4 & G & Iliamna Greene Malvaceae & 1 & $\mathrm{~F}$ \\
\hline Agoseris Raf. Asteraceae & 4 & $\mathrm{~F}$ & Koeleria Pers. Poaceae & 1 & G \\
\hline Allium L. Liliaceae & 1 & $\mathrm{~F}$ & Krascheninnikovia Guldenstaedt Chenopodiaceae & 1 & $\mathrm{~S}$ \\
\hline Arenaria L. Caryophyllaceae & 1 & $\mathrm{~F}$ & Lepidium L. Brassicaceae & 1 & $\mathrm{~F}$ \\
\hline Argemone L. Papaveraceae & 1 & $\mathrm{~F}$ & Leymus Hochst. Poaceae & 3 & G \\
\hline Aristida L. Poaceae & 1 & G & Ligusticum L. Apiaceae & 2 & $\mathrm{~F}$ \\
\hline Artemisia L. Asteraceae & 13 & S & Linum L. Linaceae & 5 & $\mathrm{~F}$ \\
\hline Astragalus L. Fabaceae & 5 & $\mathrm{~F}$ & Lomatium Raf. Apiaceae & 12 & $\mathrm{~F}$ \\
\hline Bromus L. Poaceae & 2 & G & Mentzelia L. Loasaceae & 3 & $\mathrm{~F}$ \\
\hline Castilleja Mutis ex L.f. Scrophulariaceae ${ }^{z}$ & 1 & $\mathrm{~F}$ & Microsteris gracilis (Hook) Greene Polemoniaceae & 1 & $\mathrm{~F}$ \\
\hline Chaenactis D.C. Asteraceae & 3 & $\mathrm{~F}$ & Muhlenbergia Schreb. Poaceae & 1 & G \\
\hline Chamerion Raf. ex Holub Onagraceae & 1 & $\mathrm{~F}$ & Nemophila Nutt. Hydrophyllaceae & 1 & $\mathrm{~F}$ \\
\hline Chenopodium L. Chenopodiaceae & 1 & $\mathrm{~F}$ & Nicotiana L. Solanaceae & 1 & $\mathrm{~F}$ \\
\hline Chrysothamnus Nutt. Asteraceae & 3 & $S$ & Oenothera L. Onagraceae & 1 & $\mathrm{~F}$ \\
\hline Clarkia Pursh Onagraceae & 1 & $\mathrm{~F}$ & Packera Á. Löve \& D. Löve Asteraceae & 1 & $\mathrm{~F}$ \\
\hline Cleome L. Capparaceae & 2 & $\mathrm{~F}$ & Pascopyrum Á. Löve Poaceae & 1 & G \\
\hline Collinsia Nutt. Scrophulariaceae & 2 & $\mathrm{~F}$ & Penstemon Schmidel Scrophulariaceae ${ }^{z}$ & 26 & $\mathrm{~F}$ \\
\hline Crepis L. Asteraceae & 3 & $\mathrm{~F}$ & Perideridia Rchb. Apiaceae & 1 & $\mathrm{~F}$ \\
\hline Enceliopsis (A. Gray) A. Nelson Asteraceae & 1 & $\mathrm{~F}$ & Psoralidium Rydb. Fabaceae & 1 & $\mathrm{~F}$ \\
\hline Epilobium L. Onagraceae & 1 & $\mathrm{~F}$ & Purshia DC. ex Poir. Rosaceae & 4 & $S$ \\
\hline Eriastrum Wooton \& Standl. Polemoniaceae & 1 & $\mathrm{~F}$ & Rudbeckia L. Asteraceae & 1 & $\mathrm{~F}$ \\
\hline Ericameria Nutt. Asteraceae & 1 & $\mathrm{~F}$ & Scrophularia L. Scrophulariaceae ${ }^{z}$ & 1 & $\mathrm{~F}$ \\
\hline Erigeron L. Asteraceae & 3 & $\mathrm{~F}$ & Shepherdia Nutt. Elaeagnaceae & 2 & $\mathrm{~S}$ \\
\hline Eriogonum Michx. Polygonaceae & 9 & $\mathrm{~F}$ & Sphaeralcea A. St.-Hil. Malvaceae & 5 & $\mathrm{~F}$ \\
\hline Eriophyllum Lag. Asteraceae & 1 & $\mathrm{~F}$ & Sporobolus R. Br. Poaceae & 1 & G \\
\hline Festuca L. Poaceae & 1 & G & Stanleya Nutt. Brassicaceae & 2 & $\mathrm{~F}$ \\
\hline Frasera Walter Gentianaceae & 1 & $\mathrm{~F}$ & Stenotus Nutt. Asteraceae & 1 & $\mathrm{~F}$ \\
\hline Gaillardia Foug. Asteraceae & 1 & $\mathrm{~F}$ & Thelypodium Endl. Brassicaceae & 1 & $\mathrm{~F}$ \\
\hline Gilia Ruiz \& Pav. Polemoniaceae & 2 & $\mathrm{~F}$ & Townsendia Hook. Asteraceae & 1 & $\mathrm{~F}$ \\
\hline Grayia Hook. \& Arn. Chenopodiaceae & 1 & $\mathrm{~F}$ & Veratrum L. Liliaceae & 1 & $\mathrm{~F}$ \\
\hline Hedysarum L. Fabaceae & 2 & $\mathrm{~F}$ & Vicia L. Fabaceae & 1 & $\mathrm{~F}$ \\
\hline Heliomeris Nutt. Asteraceae & 3 & $\mathrm{~F}$ & Vulpia C.C. Gmel. Poaceae & 1 & G \\
\hline Hesperostipa (Elias) Barkworth Poaceae & 1 & G & Wyethia Nutt. Asteraceae & 1 & $\mathrm{~F}$ \\
\hline
\end{tabular}

z ITIS (2015) places Castilleja in the Orobanchaceae and Penstemon in the Plantaginaceae. 
than $6 \mathrm{wk}$ old (see Table 3), they may also be an underutilized aspect to restoring degraded sites. In a California Mediterranean climate, annual native forbs seeded on sites dominated by invasive species remained abundant for several years (Seabloom and others 2003). In Oregon, a prairie restoration strategy that included multi-year sowing of natives, including annual forbs, resulted in exceptional cover of native species after $5 \mathrm{y}$; the annual forbs were thought to reduce weed establishment (Wold and others 2011). Thus, annual native forbs could be important in re-establishing sagebrush habitat and their inclusion in restoration plans deserves more attention.

\section{Controlling Invasive Grasses and Forbs}

Our best efforts to produce native plants for restoration are honorable, but successful conservation and restoration of sagegrouse habitat will, in many cases, require controlling invasive plant species (Ielmini and others 2015). One of the most important threats to the sagebrush biome and restoration of sagegrouse habitat is invasion by cheatgrass; this exotic annual grass displaces native forbs, increases fire frequency, and readily re- establishes after fire creating a self-perpetuating cheatgrass-fire loop (D’Antonio and Vitousek 1992). Unfortunately, cheatgrass is not the only invasive plant causing problems. Many invasive forb species can also degrade sagebrush habitat by outcompeting and displacing desirable native plants (Ielmini and others 2015). Nonnative forbs known to invade sagebrush habitats include several members of the Asteraceae (rush skeletonweed, Chondrilla juncea L. [Figure 10]; spotted knapweed, Centaurea stoebe L.; diffuse knapweed, C. diffusa Lam.; Russian knapweed, Acroptilon repens (L.) DC.; Canada thistle, Cirsium arvense (L.) Scop.; yellow starthistle, Centaurea solstitialis L.), 2 members of the Brassicaceae (whitetop, Cardaria Desv. spp.; Dyer's woad, Isatis tinctoria L.), and leafy spurge (Euphorbia esula L. [Euphorbiaceae]) (Miller and others 2011; Ielmini and others 2015).

Chemical herbicides are commonly used to suppress exotic weeds, but effectiveness is usually short-term; herbicides must be re-applied to maintain control and it is often economically unfeasible to apply on a landscape scale. Moreover, herbicides can, as discussed earlier, have long-lasting non-target effects on

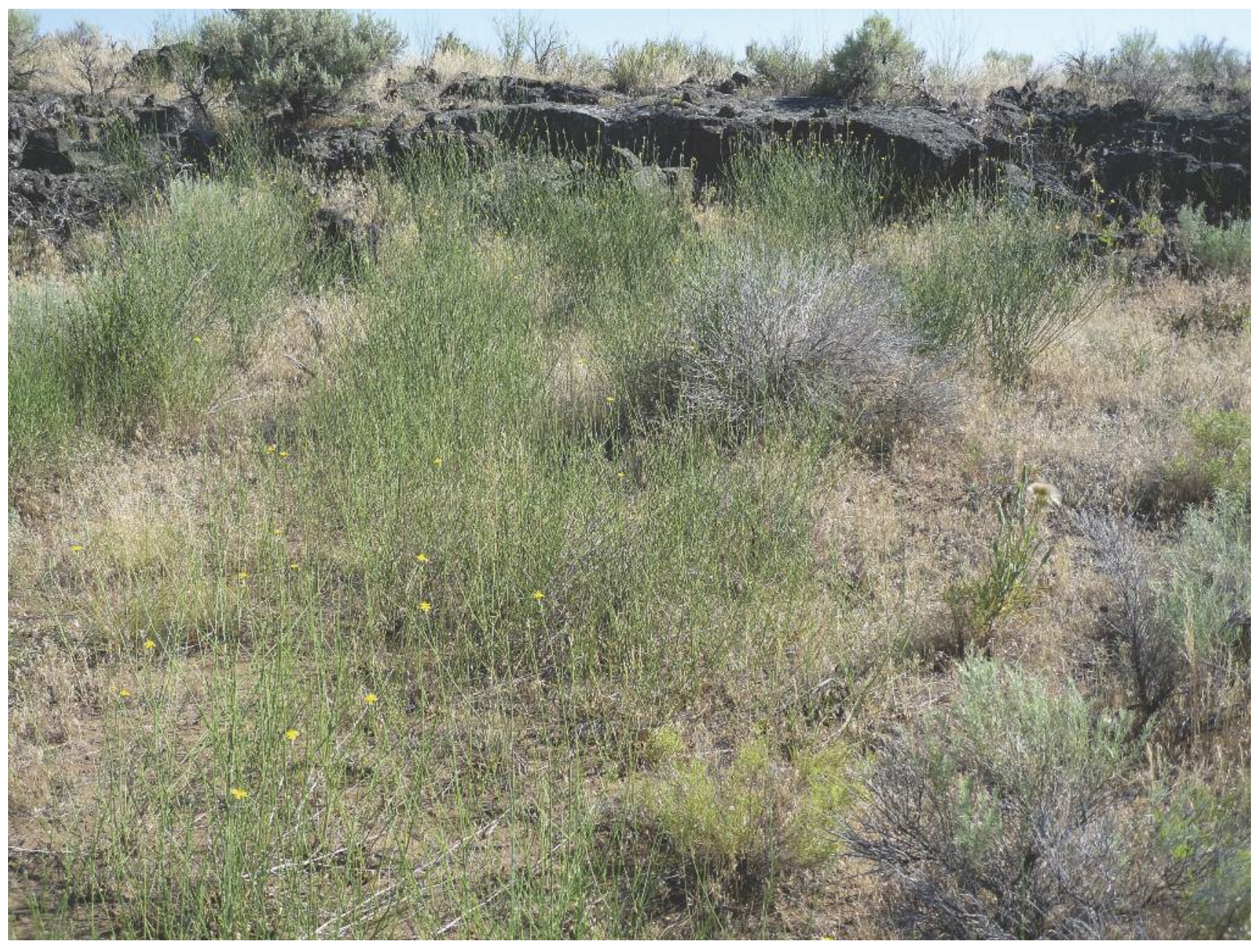

Figure 10. Nonnative rush skeletonweed (green with small, yellow flowers), invading and overrunning sagebrush habitat in Craters of the

Moon National Preserve in southern Idaho. Photo by Justin B Runyon 
native plants (Crone and others 2009), including those important to sage-grouse (Baker and others 2009; Rinella and others 2009). This underscores the need to develop other weed control tactics to minimize use of herbicides and lower non-target impacts.

Biological control, the deliberate use of a weed's natural enemies to suppress its abundance, is a crucial management tool because it is one of the few methods that can provide costeffective, host-specific, long-term control of widespread invasive plants. Ongoing biological control research at the USFS RMRS is targeting the invasive plants most threatening to sage-grouse habitat. For example, evaluation of seed pathogens, including "black fingers of death" (Pyrenophora semeniperda (Brittleb. \& D.B. Adam) Shoemaker), to control cheatgrass continues (Meyer and others 2008; Masi and others 2014; Soliai and others 2014), as does the search for, and testing of, new potential biocontrol herbivores of several invasive forb species, including rush skeletonweed (Littlefield and others 2013). RMRS scientists are also evaluating how climate change will affect invasive species and the use of biological control to manage them (Runyon and others 2012). Biological control holds great potential to safely and effectively manage invasive plants in sagebrush habitats and to serve a critical role in sage-grouse conservation.

\section{SUMMARY}

The sagebrush-dominated landscape of the western US is a rich mosaic of Artemisia species, subspecies, and hybrids foundational to a robust understory of grasses and forbs. This floral understory in turn supports diverse invertebrate communities. Together, these invertebrates and understory species are critical to the diet of GRSG; indeed, GRSG are known to consume nearly 40 genera. Thus, when an objective of restoration in the western US is to provide suitable GRSG habitat, land management protocols that incorporate a broad diversity of forb and grass species will provide more resources for GRSG and other sagebrush-steppe-dependent wildlife than management strategies that do not. To ensure restoration success, control of invasive plants is required, and biological control offers opportunity to accomplish this in a sustainable way.

\section{ACKNOWLEDGMENTS}

We thank Steven Schwarzbach, Brian Perkes, Jim Morefield, Matt Lavin, Tom Koerner, Steve Fairbairn, and Bebe Crouse for allowing us to use their photos; and Candace Akins, Deborah Finch, Steve Love, Mary I Williams, and 2 anonymous reviewers for insightful comments and suggestions. This work was supported by the USFS Rocky Mountain Research Station and the National Center for Reforestation, Nurseries, and Genetics Re-

\section{REFERENCES}

Aldridge CL, Boyce MS. 2007. Linking occurrence and fitness to persistence: habitat-based approach for endangered greater sagegrouse. Ecological Applications 17:508-526.

[AOU] American Ornithologists' Union. 2015. AOU checklist of North and Middle American Birds. 7th edition and supplements. URL: http://www.americanornithology.org/content/aou-checklist-northand-middle-american-birds-7th-edition-and-supplements\#sthash.m SOIBAAQ.dpuf (accessed 25 Sep 2015). Washington, DC.

Archibald C. 2006. Seed production protocols for Anaphalis margaritacea, Eriophyllum lanatum, and Eriogonum umbellatum. Native Plants Journal 7:47-51.

Archibald C, Feigner S, Visser J. 2000. Seed and seedling production of blue wild-rye (Elymus glaucus). Native Plants Journal 1:32-34.

Arkle RS, Pilliod DS, Hanser SE, and 7 others. 2014. Quantifying restoration effectiveness using multi-scale habitat models: implications for sage-grouse in the Great Basin. Ecosphere 5:1-32.

Baldwin BG, Boyd S, Ertter BJ, Patterson RW, Rosatti TJ, Wilken DH, editors. 2002. The Jepson desert manual: vascular plants of Southeastern California. Berkeley (CA): University of California Press. 1568 p.

Baldwin BG, Goldman DH, Keil DJ, Patterson R, Rosatti TJ, Wilken DH, editors. 2012. The Jepson manual: vascular plants of California. Berkeley (CA): University of California Press. 624 p.

Baker WL, Garner J, Lyon P. 2009. Effect of imazapic on cheatgrass and native plants in Wyoming big sagebrush restoration for Gunnison sage-grouse. Natural Areas Journal 29:204-209.

Barker JR, McKell CM. 1983. Habitat differences between basin and Wyoming big sagebrush in contiguous populations. Journal of Range Management 36:450-454.

Barnett JK. 1992. Diet and nutrition of female sage grouse during the pre-laying period [MSc thesis]. Corvallis (OR): Oregon State University. $46 \mathrm{p}$.

Barnett JK, Crawford JA. 1994. Pre-laying nutrition of sage grouse hens in Oregon. Journal of Range Management 47:114-118.

Baskin CJ, Baskin JM. 1998. Seeds: ecology, biogeography and evolution in dormancy and germination. San Diego (CA): Academic Press. $666 \mathrm{p}$.

Beck JL, Mitchell DL, Maxfield BD. 2003. Changes in the distribution and status of sage-grouse in Utah. Western North American Naturalist 63:203-214.

Beck JL, Connelly JW, Wambolt CL. 2012. Consequences of treating Wyoming big sagebrush to enhance wildlife habitats. Rangeland Ecology and Management 65:444-455.

Belnap J, Eldridge D. 2003, Disturbance and recovery of biological soil crusts. In: Belnap J, Lange OL, editors. Biological soil crusts: structure, function, and management. Berlin: Springer-Verlag. p 363383.

Bergquist E, Evangelista P, Stohlgren T], Alley N. 2007. Invasive species and coal bed methane development in the Powder River Basin, Wyoming. Environmental Monitoring and Assessment 128:381394.

Blickley JL, Blackwood D, Patricelli GL. 2012. Experimental evidence for the effects of chronic anthropogenic noise on abundance of greater sage-grouse leks. Conservation Biology 26:461-471.

Blus LJ, Staley CS, Henny CJ, and 4 others. 1989. Effects of organophosphorus insecticides on sage grouse in southeastern Idaho. Journal of Wildlife Management 53:1139-1146.

Bower AD, St Clair JB, Erickson VJ. 2014. Generalized provisional seed zones for native plants. Ecological Applications 24:913-919. 
Boyer L. 2008. Providing native plant diversity to the Willamette Valley Ecoregion. Native Plants Journal 9:230-240.

Brabec MM, Germino MJ, Shinneman DJ, Pilliod DS, Mcllroy SK, Arkle RS. 2015. Challenges of establishing big sagebrush (Artemisia tridentata) in rangeland restoration: effects of herbicide, mowing, wholecommunity seeding, and sagebrush seed sources. Rangeland Ecology and Management 68:432-435.

Braun CE, Connelly JW, Schroeder MA. 2005. Seasonal habitat requirements of sage-grouse: spring, summer, fall and winter. In: Shaw NL, Pellant M, Monsen SB, compilers. Sage-Grouse Habitat Restoration Symposium Proceedings. Fort Collins (CO): USDA Forest Service, Rocky Mountain Research Station. Proceedings RMRS-P-38. p 3842.

Campbell RK. 1991. Soils, seed-zone maps, and physiography: guidelines for seed transfer of Douglas-fir in southwestern Oregon. Forest Science 37:973-986.

Chambers JC, Roundy BA, Blank RR, Meyer SE, Whittaker A. 2007. What makes Great Basin sagebrush ecosystems invasible by Bromus tectorum? Ecological Monographs 77:117-145.

Chambers JC, Miller RF, Grace JB, and 4 others. 2014. Resilience to disturbance and resistance to invasive alien grasses in arid and semiarid ecosystems: lessons from the cold desert. Ecosystems 17:360375.

Chambers KJ, Bowen P, Turner NJ, Keller PC. 2006. Ethylene improves germination of arrowleaved balsamroot seeds. Native Plants Journal 7:108-113.

Connelly JW, Braun CE. 1997. Long-term changes in sage grouse Centrocercus urophasianus populations in western North America. Wildlife Biology 3:229-234.

Connelly JW, Browers HW, Gates RJ. 1988. Seasonal movements of sage grouse in southeastern Idaho. Journal of Wildlife Management $52: 116-122$.

Connelly JW, Shroeder MA, Sands AR, Braun CE. 2000. Guidelines to manage sage grouse and their habitats. Wildlife Society Bulletin 28:967-985.

Connelly JW, Knick ST, Shroeder MA, Shriver SJ. 2004. Conservation assessment of greater sage grouse and sagebrush habitats. Cheyenne (WY): Western Association of Fish and Wildlife Agencies. 611 p.

Connelly JW, Knick ST, Braun CE, and 17 others. 2011. Conservation of greater sage-grouse: a synthesis of current trends and future management. In: Knick ST, Connelly JW, editors. Greater Sage-Grouse: ecology and conservation of a landscape species and its habitats. Berkeley (CA): University of California Press. Studies in Avian Biology 38:549-653.

Connelly JW, Musil DD, Forbey JS. 2013. Phytochemistry predicts habitat selection by an avian herbivore at multiple spatial scales. Ecology 94:308-314.

Crawford JA, Olson RA, West NE, and 6 others. 2004. Ecology and management of sage-grouse and sage-grouse habitat. Rangeland Ecology and Management 57:2-19.

Crone EE, Marler M, Pearson DE. 2009. Non-target effects of broadleaf herbicide on a native perennial forb: a demographic framework for assessing and minimizing impacts. Journal of Applied Ecology 46:673-682.

Cronquist A, Holmgren NH, Holmgren PH, Reveal J. 1972-2012. Intermountain flora: vascular plants of the Intermountain West. Volumes 1-6. New York (NY): New York Botanical Garden Press.

D'Antonio CM, Vitousek PM. 1992. Biological invasions by exotic grasses, the grass-fire cycle, and global change. Annual Review of Ecology and Systematics 23:63-87.

Davies KW, Boyd CS, Beck JL, Bates JD, Svejcar TJ, Gregg MA. 2011.
Saving the sagebrush sea: an ecosystem conservation plan for big sagebrush plant communities. Biological Conservation 144:25732584.

Davis AS, Herriman KR, Apostol KG, Kildisheva OA, Ross-Davis AL, Dumroese RK. Forthcoming. Do container volume, site preparation, and field fertilization affect restoration potential of Wyoming big sagebrush? Natural Areas Journal.

Davis DM. 2002. Breeding season habitat use and management activities by Greater Sage Grouse on Sheldon Wildlife Refuge, Nevada [MSc thesis]. Corvallis (OR): Oregon State University. 146 p.

Doherty KE, Naugle DE, Walker BL, Graham JM. 2008. Greater sagegrouse winter habitat selection and energy development. Journal of Wildlife Management 72:187-195.

Dow Chemical Company. 2015. Materials safety data sheet: 2, 4-D amine 480 SL. URL: http://msdssearch.dow.com/PublishedLiterature DAS/dh_0060/0901b8038006067f.pdf (accessed 2015). Indianapolis (IN): Dow AgroSciences LLC.

Drut MS, Crawford JA, Gregg MA. 1994a. Brood habitat use by sage grouse in Oregon. Western North American Naturalist 54:170-176.

Drut MS, Pyle WH, Crawford JA. 1994b. Diets and food selection of sage grouse chicks in Oregon. Journal of Range Management 47:90-93.

Dunn PO, Braun CE. 1986. Late summer-spring movements of juvenile sage-grouse. Wilson Bulletin 98:83-92.

Dunne RA, Dunne CG. 2002. Potential for expanded production of native rangeland seeds in western North America. Native Plants Journal 3:34-37.

Ellis KL, Parrish JL, Murphy JR, Richins GH. 1989. Habitat use by breeding male sage grouse: a management approach. Great Basin Naturalist 49:404-407.

Eng RL, Schladweiler P. 1972. Sage grouse winter movements and habitat use in central Montana. Journal of Wildlife Management 36:141-146.

Ersch E. 2009. Plant community characteristics on insect abundance: implications on sage-grouse brood rearing habitats [MSc thesis]. Corvallis (OR): Oregon State University. 109 p.

Farr DF, Rossman AY. 2015. Fungal databases. Systematic mycology and microbiology laboratory nomenclature database. URL: http:// nt.ars-grin.gov/fungaldatabases/ (accessed 14 Sep 2015). Washington (DC): USDA Agricultural Research Service.

Federal Register. 2014. Endangered and threatened wildlife and plants; threatened status for Gunnison Sage-Grouse. Federal Register 79(224):69192-69310.

Finch D, Chamber J, Kitchen S, and 6 others. 2015. Sage-grouse conservation science strategy 2015-2020. Washington (DC): USDA Forest Service. 39 p.

Fleege CK. 2010. Protocols for sagebrush seed processing and seedling production at the Lucky Peak Nursery. In: Riley LE, Pinto JR, Dumroese RK, technical coordinators. National Proceedings: Forest and Conservation Nursery Associations-2009. Fort Collins (CO): USDA Forest Service, Rocky Mountain Research Station. Proceedings RMRS-P-62. p 33-35.

Garcia S, Garnatje T, McArthur ED, Pellicer J, Sanderson SC, Valles J. 2011. Taxonomic and nomenclatural rearrangements in Artemisia subgen. Tridentatae, including a redefinition of Sphaeromeria (Asteraceae, Anthemideae). Western North American Naturalist 71:158163.

Garrison HD, Shultz LM, McArthur ED. 2013. Studies of a new hybrid taxon in the Artemisia tridentata (Asteraceae: Anthemideae) complex. Western North American Naturalist 73:1-19. 
Gelbard JL, Belnap J. 2003. Roads as conduits for exotic plant invasions in a semiarid landscape. Conservation Biology 17:420-432.

Goodrich S. 2005. Classification and capabilities of woody sagebrush communities with emphasis on sage grouse habitat. In: Shaw NL, Pellant M, Monsen SB, compilers. Sage-Grouse Habitat Restoration Symposium Proceedings. Fort Collins (CO): USDA Forest Service, Rocky Mountain Research Station. Proceedings RMRS P-38. $\mathrm{p}$ 17-37.

Gregg MA. 2006. Greater sage-grouse reproductive ecology: linkages among habitat resources, maternal nutrition, and chick survival [PhD dissertation]. Corvallis (OR): Oregon State University. 201 p.

Gregg MA, Crawford JA. 2009. Survival of greater sage-grouse chicks and broods in the northern Great Basin. Journal of Wildlife Management 73:904-913.

Gregg MA, Crawford JA, Drut MS, Delong AK. 1994. Vegetational cover and predation of sage-grouse nests in Oregon. Journal of Wildlife Management 58:162-166.

Gregg MA, Barnett JK, Crawford JA. 2008. Temporal variation in diet and nutrition of pre-incubating sage grouse. Rangeland Ecology and Management 61:535-542.

Hackett SJ, Kimball RT, Reddy S, and 15 others. 2008. A phylogenomic study of birds reveals their evolutionary history. Science 320:17631768.

Hagen CA, Connelly JW, Shroeder MA. 2007. A meta-analysis of greater sage-grouse Centrocercus urophasianus nesting and brood-rearing habitats. Wildlife Biology 13:42-50.

Hannon SJ, Martin K. 2006. Ecology of juvenile grouse during the transition to adulthood. Journal of Zoology 269:422-433.

Helliwell R. 2010. A new Lomatium (Apiaceae) from the Ochoco Mountains of central Oregon. Journal of the Botanical Research Institute of Texas 4:7-11.

Hitchcock CL, Cronquist A, Ownbey M, Thompson JW. 1987. Flora of the Pacific Northwest. Part 3: Saxifragaceae to Ericaceae. Seattle (WA): University of Washington Press. 614 p.

Holloran MJ. 2005. Greater sage-grouse (Centrocercus urophasianus) population response to natural gas field development in western Wyoming [PhD dissertation]. Laramie (WY): University of Wyoming. $215 \mathrm{p}$.

Hufford KM, Mazer SJ. 2003. Plant ecotypes: genetic differentiation in the age of ecological restoration. Trends in Ecology and Evolution 18:147-155.

Hull AC Jr, Kissinger NA Jr, Vaughn WT. 1952. Chemical control of sagebrush in Wyoming. Journal of Range Management 5:398-402.

lelmini MR, Hopkins TE, Mayer KE, and 5 others. 2015. Invasive plant management and greater sage-grouse conservation: a review and status report with strategic recommendations for improvement. Cheyenne (WY): Western Association of Fish and Wildlife Agencies. $47 \mathrm{p}$.

Ingelfinger F, Anderson S. 2004. Passerine response to roads associated with natural gas extraction in a sagebrush steppe habitat. Western North American Naturalist 64:385-395.

[ITIS] Integrated Taxonomic Information System. 2015. URL: http://itis. gov (accessed 14 Sep 2015). Washington (DC): National Museum of Natural History.

Jacobs J, Winslow SR, Clause K, Parr S. 2013. Native grass establishment and performance for well-pad reclamation in Wyoming. USDA Natural Resources Conservation Service. Plant Materials Technical Note MT-90. 21 p.

Johnson GD, Boyce MS. 1990. Feeding trials with insects in the diet of sage grouse chicks. Journal of Wildlife Management 54:89-91.
What are the best seed sources for ecosystem restoration on BLM and USFS lands? Native Plants Journal 11:117-131.

Johnson RC, Hellier BC, Vance-Borland KW. 2013. Genecology and seed zones for tapertip onion in the US Great Basin. Botany 91:686694.

Jones TA, Parr SD, Winslow SR, Rosales MA. 2009. Notice of release of 'Continental' basin wildrye. Native Plants Journal 10:57-61.

Kaiser RC. 2006. Recruitment by greater sage-grouse in association with natural gas development in western Wyoming [MSc thesis]. Laramie (WY): University of Wyoming. 102 p.

Karrfalt RP, Shaw N. 2013. Banking Wyoming big sagebrush seeds. Native Plants Journal 14:60-70.

Kelsey RG, Wright WE, Sneva F, Winward A, Britton C. 1983. The concentration and composition of big sagebrush essential oils from Oregon. Biochemical Systematics and Ecology 11:353-360.

Kilkenny FF. 2015. Genecological approaches to predicting the effects of climate change on plant populations. Natural Areas Journal 35:152-164.

Kitchen SG, McArthur ED. 2007. Big and black sagebrush landscapes. In: Hood SM, Miller M, editors. Fire Ecology and Management of the Major Ecosystems of Southern Utah. Fort Collins (CO): USDA Forest Service, Rocky Mountain Research Station. General Technical Report RMRS-GTR-202. p 73-95.

Klebenow DA, Gray GM. 1968. Food habits of juvenile sage grouse. Journal of Range Management 21:80-83.

Knick ST, Dobkin DS, Rotenberry JT, Schroeder MA, Vander Haegen WM, van Riper C III. 2003. Teetering on the edge or too late? Conservation and research issues for avifauna of sagebrush habitats. Condor 105:611-634.

Krabacher P. 2015. Personal communication. Boise (ID): USDI Bureau of Land Management. National Seed Coordinator.

Lambert SM. 2005. Seeding considerations in restoring big sagebrush habitat. In: Shaw NL, Pellant M, Monsen SB, compilers. SageGrouse Habitat Restoration Symposium Proceedings. Fort Collins (CO): USDA Forest Service, Rocky Mountain Research Station. Proceedings RMRS-P-38. p 75-80.

Landis TD. 2008. The target plant concept. In: Dumroese RK, Luna T, Landis TD, editors. Nursery manual for native plants: a guide for tribal nurseries. Volume 1: Nursery management. Washington (DC): USDA Forest Service. Agriculture Handbook 730. p 18-31.

Landis TD, Dumroese RK. 2015. Propagating native milkweeds for restoring monarch butterfly habitat. International Plant Propagators' Society, 2014 Combined Proceedings 64:299-307.

LeBeau CW. 2012. Evaluation of greater sage-grouse reproductive habitat and response to wind energy development in south-central Wyoming [MSc thesis]. Laramie (WY): University of Wyoming. $138 \mathrm{p}$.

Leger EA. 2008. The adaptive value of remnant native plants in invaded communities: an example from the Great Basin. Ecological Applications 18:1226-1235.

Leger EA, Baughman OW. 2015. What seeds to plant in the Great Basin? Comparing traits prioritized in native plant cultivars and releases with those that promote survival in the field. Natural Areas Journal 35:54-68.

Leonard KM, Reese KP, Connelly JW. 2000. Distribution, movements and habitats of sage grouse Centrocercus urophasianus on the upper Snake River plain of Idaho: changes from the 1950's to the 1990's. Wildlife Biology 6:265-270.

Lesica P, Allendorf FW. 1999. Ecological genetics and the restoration of plant communities: mix or match? Restoration Ecology 7:42-50. Linhart YB, Grant MC. 1996. Evolutionary significance of local genetic 
differentiation in plants. Annual Review of Ecology and Systematics 27:237-277.

Littlefield JL, Markin G, Kashefi J, de Meij A, Runyon J. 2013. The release and recovery of Bradyrrhoa gilveolella on rush skeletonweed in southern Idaho. In: Wu Y, Johnson T, Sing S, and 7 others, editors. Proceedings of the XIII International Symposium on Biological Control of Weeds. Fort Collins (CO): USDA Forest Service, Forest Health Technology Enterprise Team.

Long B, Trimmer E. 2004. Propagation protocol for bareroot sagebrush Artemisia spp. Native Plants Journal 5:149-151.

Love SL, Tripepi RR, Salaiz T. 2014a. Influence of harvest timing and storage interval on rabbitbrush seed germination, emergence, and viability. Native Plants Journal 15:98-108.

Love SL, Tripepi RR, Salaiz T. 2014b. Influence of stratification, light, and planting depth on rabbitbrush seed germination. Native Plants Journal 15:109-118.

Luna T. 2005. Propagation protocol for Indian paintbrush (Castilleja species). Native Plants Journal 6:62-68.

Lyon AG, Anderson SH. 2003. Potential gas development impacts on sage grouse nest initiation and movement. Wildlife Society Bulletin 31:486-491.

Mahalovich MF, McArthur ED. 2004. Sagebrush (Artemisia spp.) seed and plant transfer guidelines. Native Plants Journal 5:141-148.

Martin NS. 1970. Sagebrush control related to habitat and sage grouse occurrence. Journal of Wildlife Management 34:313-320.

Masi M, Meyer S, Clement S, Andolfi A, Cimmino A, Evidente A. 2014. Spirostaphylotrichin $\mathrm{W}$, a spirocyclic gamma-lactam isolated from liquid culture of Pyrenophora semeniperda, a potential mycoherbicide for cheatgrass (Bromus tectorum) biocontrol. Tetrahedron 70:1497-1501.

McArthur ED, Sanderson SC. 1999. Cytogeography and chromosome evolution of subgenus Tridentatae of Artemisia (Asteraceae). American Journal of Botany 86:1754-1775.

McArthur ED, Welch BL. 1982. Growth rate differences among big sagebrush [Artemisia tridentata] accessions and subspecies. Journal of Range Management 35:396-401.

McArthur ED, Welch BL, Sanderson SC. 1988. Natural and artificial hybridization between big sagebrush (Artemisia tridentata) subspecies. Journal of Heredity 79:268-276.

McKay JK, Christian CE, Harrison S, Rice KJ. 2005. "How local is local?" A review of practical and conceptual issues in the genetics of restoration. Restoration Ecology 13:432-440.

Menzel A, Sparks TH, Estrella N, and 28 others. 2006. European phenological response to climate change matches the warming pattern. Global Change Biology 12:1969-1976.

Meyer SE. 2006. Strategies for seed propagation of native forbs. In: Riley LE, Dumroese RK, Landis TD, technical coordinators. 2006. National Proceedings, Forest and Conservation Nursery Associations2005. Fort Collins (CO): USDA Forest Service, Rocky Mountain Research Station. Proceedings RMRS-P-43. p 3-9.

Meyer SE, Paulsen A. 2000. Chilling requirements for seed germination of 10 Utah species of perennial wild buckwheat. Native Plants Journal 1:18-24.

Meyer SE, Nelson DL, Clement S, Beckstead J. 2008. Cheatgrass (Bromus tectorum) biocontrol using indigenous fungal pathogens. In: Kitchen SG, Pendleton RL, Monaco TA, Vernon J, compilers. 2008. Proceedings-Shrublands under Fire: Disturbance and Recovery in a Changing World. Fort Collins (CO): USDA Forest Service, Rocky Mountain Research Station. Proceedings RMRS-P-52. p 61-67.

Miglia KJ, McArthur ED, Redman RS, Rodriguez RJ, Zak JC, Freeman DC. 2007. Genotype, soil type, and locale effects on reciprocal trans- plant vigor, endophyte growth, and microbial functional diversity of a narrow sagebrush hybrid zone in Salt Creek Canyon, Utah. American Journal of Botany 94:425-436.

Miller RF, Knick ST, Pyke DA, and 4 others. 2011. Characteristics of sagebrush habitat and limitations to long-term conservation. In: Knick ST, Connelly JW, editors. Greater Sage-Grouse: ecology and conservation of a landscape species and its habitats. Berkeley (CA): University of California Press. Studies in Avian Biology 38:145-184.

NatureServe. 2014. Ecological communities database. URL: http://www.natureserve.org/ (accessed Dec 2014). Arlington (VA).

Noss RF, LaRoe ET III, Scott JM. 1995. Endangered ecosystems of the United States: a preliminary assessment of loss and degradation. Washington (DC): National Biological Service. Biological Report 28.

[NPN] Native Plant Network. 2015. Native Plant Network database. URL: http://www.nativeplantnetwork.org/network/ (accessed Jun 2015). Athens (GA): Reforestation, Nurseries \& Genetics Resources (RNGR).

Olson RA, Whitson TD. 2002. Restoring structure in late-successional sagebrush communities by thinning with tebuthiuron. Restoration Ecology 10:146-155.

Overton EC, Davis AS, Pinto JR. 2013. Insights into big sagebrush storage practices. Native Plants Journal 14:225-230.

Parkinson H, Zabinski C, Shaw N. 2013. Impact of native grasses and cheatgrass on forb seedling growth. Rangeland Ecology and Management 66:174-180.

[PCA] Plant Conservation Alliance. 2015. National Seed Strategy for Rehabilitation and Restoration 2015-2020. URL: http://www.blm. gov/ut/st/en/prog/more/CPNPP/0/seedstrategy.html (accessed 25 Sep 2015). Washington (DC): US Department of the Interior, Bureau of Land Management.

Peterson JG. 1970. The food habits and summer distribution of juvenile sage grouse in central Montana. Journal of Wildlife Management 34:147-155.

Prevéy JS, Germino MJ, Huntley NJ. 2010a. Loss of foundation species increases population growth of exotic forbs in sagebrush steppe. Ecological Applications 20:1890-1902.

Prevéy JS, Germino MJ, Huntley NJ, Inouye RS. 2010b. Exotic plants increase and native plants decrease with loss of foundation species in sagebrush steppe. Plant Ecology 207:39-51.

Pyle WH. 1992. Response of brood-rearing habitat of sage grouse to prescribed burning in Oregon [MSc thesis]. Corvallis (OR): Oregon State University. 47 p.

Rehfeldt GE, Crookston NL, Saenz-Romero C, Campbell EM. 2012. North American vegetation model for land-use planning in a changing climate: a solution to large classification problems. Ecological Applications 22:119-141.

Remington TE, Braun CE. 1985. Sage grouse food selection in winter, North Park, Colorado. Journal of Wildlife Management 49:10551061.

Rhodes EC, Bates JD, Sharp RN, Davies KW. 2010. Fire effects on cover and dietary resources of sage grouse habitat. Journal of Wildlife Management 74:755-764.

Richardson BA, Page JT, Bajgain P, Sanderson SC, Udall JA. 2012. Deep sequencing of amplicons reveals widespread intraspecific hybridization and multiple origins of polyploidy in big sagebrush (Artemisia tridentata: Asteraceae). American Journal of Botany 99:1962-1975.

Richardson BA, Ortiz HG, Carlson SL, Jaeger DM, Shaw NL. 2015. Genetic and environmental effects on seed weight in subspecies of big sagebrush: applications for restoration. Ecosphere 6: article 201.

Rinella MJ, Maxwell BD, Fay PK, Weaver T, Sheley RL. 2009. Control ef- 
fort exacerbates invasive-species problem. Ecological Applications 19:155-162.

Rosentreter R. 2005. Sage identification, ecology and palatability relative to sage grouse. In: Shaw NL, Pellant M, Monsen SB, compilers. Sage-Grouse Habitat Restoration Symposium Proceedings. Fort Collins (CO): USDA Forest Service, Rocky Mountain Research Station. Proceedings RMRS-P-38. $\mathrm{p}$ 1-15.

Runyon JB, Butler JL, Friggens MM, Meyer SE, Sing SE. 2012. Invasive species and climate change. In: Finch DM, editor. Climate Change in Grasslands, Shrublands, and Deserts of the Interior American West: a Review and Needs Assessment. Fort Collins (CO): USDA Forest Service, Rocky Mountain Research Station. General Technical Report RMRS-GTR-285. Chapter 7: 97-115.

Schlaepfer DR, Taylor KA, Pennington VE, and 5 others. 2015. Simulated big sagebrush regeneration supports predicted changes at the trailing and leading edges of distribution shifts. Ecosphere 6: article 3.

Schneegas ER. 1967. Sage grouse and sagebrush control. Transactions of the North American Wildlife and Natural Resources Conference 32:270-274.

Schrag A, Konrad S, Miller S, Walker B, Forrest S. 2011. Climate-change impacts on sagebrush habitat and West Nile virus transmission risk and conservation implications for greater sage-grouse. GeoJournal 76:561-575.

Seabloom EW, Borer ET, Boucher VL, and 6 others. 2003. Competition, seed limitation, disturbance, and reestablishment of California annual forbs. Ecological Applications 13:575-592.

Shaw NL, DeBolt AM, Rosentreter R. 2005. Reseeding big sagebrush: techniques and issues. In: Shaw NL, Pellant M, Monsen SB, compilers. Sage-Grouse Habitat Restoration Symposium Proceedings. Fort Collins (CO): USDA Forest Service, Rocky Mountain Research Station. Proceedings RMRS-P-38. p 99-108.

Shaw NL, Lambert SM, DeBolt AM, Pellant M. 2005. Increasing native forb seed supplies for the Great Basin. In: Dumroese RK, Riley LE, Landis TD, technical coordinators. National Proceedings, Forest and Conservation Nursery Associations-2004. Fort Collins (CO): USDA Forest Service, Rocky Mountain Research Station. Proceedings RMRS-P-35. p 94-102.

Shaw N, Pellant M, Fisk M, Denney E. 2012. A collaborative program to provide native plant materials for the Great Basin. Rangelands 34:11-16.

Shock CC, Feibert EBG, Shaw N, Shock M, Saunders LD. 2015. Irrigation to enhance native seed production for Great Basin restoration. Natural Areas Journal 35:74-82.

Shultz LM. 2006. Artemisia. In: Flora of North America Editorial Committee. 1993+. Flora of North America north of Mexico. 19:503520. New York and Oxford: Oxford University Press.

Shultz LM. 2012. A pocket guide to sagebrush. URL: http://www. sagestep.org/pubs/pubs/sagebrush_pock_guide.pdf (accessed 27 Jan 2015).

Smith R. 2013. Conserving Montana's sagebrush highway: long distance migration in sage grouse [MSc thesis]. Missoula (MT): University of Montana. $47 \mathrm{p}$.

Smith SR, Whalley RDB. 2002. A model for expanded use of native grasses. Native Plants Journal 3:38-49.

Soliai MM, Meyer SE, Udall JA, and 5 others. 2014. De novo genome assembly of the fungal plant pathogen Pyrenophora semeniperda. PLoS One 9(1): e87045. doi: 10.1371/journal.pone.0087045.

St Clair JB, Kilkenny FF, Johnson RC, Shaw NL, Weaver G. 2013. Genetic variation in adaptive traits and seed transfer zones for Pseudoroegneria spicata (bluebunch wheatgrass) in the northwestern United States. Evolutionary Applications 6:933-948.
Stevens R, McArthur ED. 1974. A simple field technique for identification of some sagebrush taxa. Journal of Range Management 27:325-326.

Still SM, Richardson BA. 2015. Projections of contemporary and future climate niche for Wyoming big sagebrush (Artemisia tridentata subsp. wyomingensis): a guide for restoration. Natural Areas Journal 35:30-43.

Stiver SJ, Rinkes ET, Naugle DE, Makela PD, Nance DA, Karl JW, editors. 2015. Sage-Grouse habitat assessment framework: a multiscale assessment tool. Denver (CO): USDI Bureau of Land Management and Western Association of Fish and Wildlife Agencies. Technical Reference 6710-1. $116 \mathrm{p}$.

Sveum CM, Crawford JA, Edge WD. 1998. Use and selection of broodrearing habitat by sage grouse in south central Washington. Western North American Naturalist 58:344-351.

Thacker ET, Gillen RL, Gunter SA, Springer TL. 2012. Chemical control of sand sagebrush: implications for lesser prairie chicken habitat. Rangeland Ecology and Management 65:516-522.

Thompson KM, Holloran MJ, Slater SJ, Kuipers JL, Anderson SA. 2006. Early brood-rearing habitat use and productivity of greater sagegrouse in Wyoming. Western North American Naturalist 66:332342.

Trueblood RW. 1954. The effect of grass reseeding in sagebrush lands on sage grouse populations [MSc thesis]. Logan (UT): Utah State Agricultural College. 78 p.

[UGRB] Upper Green River Basin Local Sage Grouse Working Group. 2015. Beneficial seed matrix for sage grouse, mule deer, antelope and associated sage steppe species of the Upper Green River. URL: http:// www.wyowildlife.com/upload/file/sage-grouse_seed_brochure.pdf (accessed 1 Oct 2015).

[USDA NRCS] USDA Natural Resources Conservation Service. 2007. Sage-grouse habitat restoration. Getting started in the Dakotas. URL: http://www.nrcs.usda.gov/Internet/FSE_PLANTMATERIALS/ publications/ndpmctn7087.pdf (accessed 25 Sep 2015). Bismarck (ND): Bismarck Plant Materials Center.

[USDA NRCS] USDA Natural Resources Conservation Service. 2015. The PLANTS database. URL: http://plants.usda.gov (accessed $14 \mathrm{Sep}$ 2015). Greensboro (NC): National Plant Data Team.

[USDI] US Department of the Interior. 2015. Historic conservation campaign protects Greater Sage-Grouse. URL: https://www.doi.gov/ pressreleases/historic-conservation-campaign-protects-greater-sagegrouse (accessed 26 Sep 2015).

Vale TR. 1974. Sagebrush conversion projects: an element of contemporary environmental change in the western United States. Biological Conservation 6:274-284.

Walker BL, Naugle DE, Doherty KE. 2007. Greater sage-grouse population response to energy development and habitat loss. Journal of Wildlife Management 71:2644-2654.

Wallestad R. 1975. Life history and habitat requirements of sage grouse in central Montana. Helena (MT): Montana Fish and Game Department. $65 \mathrm{p}$.

Wallestad R, Peterson JG, Eng RL. 1975. Foods of adult sage grouse in central Montana. Journal of Wildlife Management 39:628-630.

Wang T, O'Neil GA, Aitken SN. 2010. Integrating environmental and genetic effects to predict responses of tree populations to climate. Ecological Applications 20:153-163.

Welch BL, McArthur ED. 1981. Variation of monoterpenoid content among subspecies and accessions of Artemisia tridentata grown in a uniform garden. Journal of Range Management 34:380-384.

Wilt FM, Geddes JD, Tamma RV, Miller GC, Everett RL. 1992. Interspecific variation of phenolic concentrations in persistent leaves among 
six taxa from subgenus Tridentatae of Artemisia (Asteraceae). Biochemical Systematics and Ecology 20:41-52.

Wold EN, Jancaitis JE, Taylor TH, Steeck DM. 2011. Restoration of agricultural fields to diverse wet prairie plant communities in the Willamette Valley, Oregon. Northwest Science 85:269-287.

Woodruff KJ, Regan DJ, Davis AS. 2014. Propagation protocol for pinyon pine (Pinus edulis Engelm.). Native Plants Journal 14:205208.

Ying CC, Yanchuk AD. 2006. The development of British Columbia's tree seed transfer guidelines: purpose, concept, methodology, and implementation. Forest Ecology and Management 227:1-13.

\section{AUTHOR INFORMATION}

R Kasten Dumroese

Research Plant Physiologist

USDA Forest Service, Rocky Mountain Research Station

1221 South Main Street

Moscow, ID 83843

kdumroese@fs.fed.us

Tara Luna

Botanist

PO Box 447

East Glacier Park, MT 59434

tluna@3rivers.net

Bryce A Richardson

Research Geneticist_-Plants

USDA Forest Service, Rocky Mountain Research Station

735 North 500 East

Provo, UT 84606

brichardson02@fs.fed.us

Francis F Kilkenny

Research Biologist

USDA Forest Service, Rocky Mountain Research Station

322 East Front Street

Boise, ID 83702

ffkilkenny@fs.fed.us

Justin B Runyon

Research Entomologist

USDA Forest Service, Rocky Mountain Research Station

1648 South 7th Avenue

Bozeman, MT 59717

jrunyon@fs.fed.us

\section{The Largest Wholesale Aquatic Nursery in the Midwest}

Illinois $\cdot$ Indiana $\cdot$ lowa $\cdot$ Michigan $\cdot$ Minnesota $\cdot$ Ohio $\cdot$ Wisconsin

\section{Producers of Plant Materials for Large Scale Wetland Mitigation and Native Restoration Quality Native Plants}

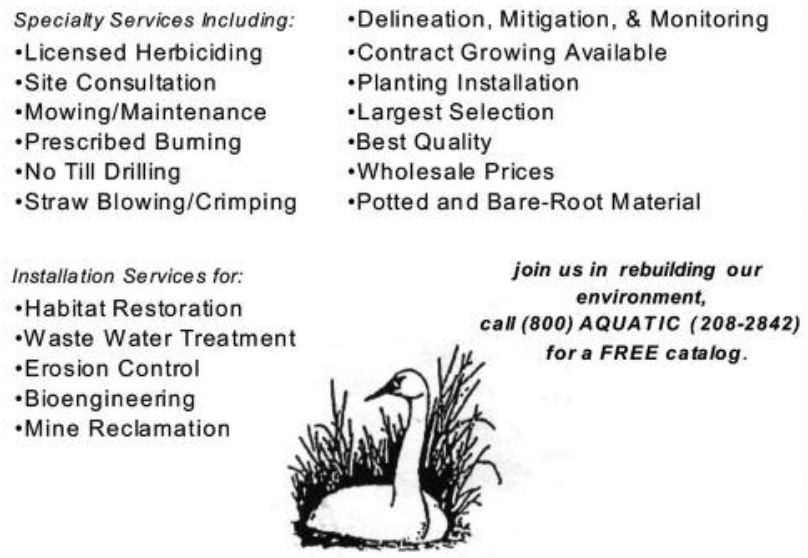

MARSHLAND TRANSPLANT AQUATIC NURSERY P.O. Box 1 Berlin, WI 54923

(920)361-4200 Fax (24 hours): (920)361-4200 e-mail marshland@centurytel.net

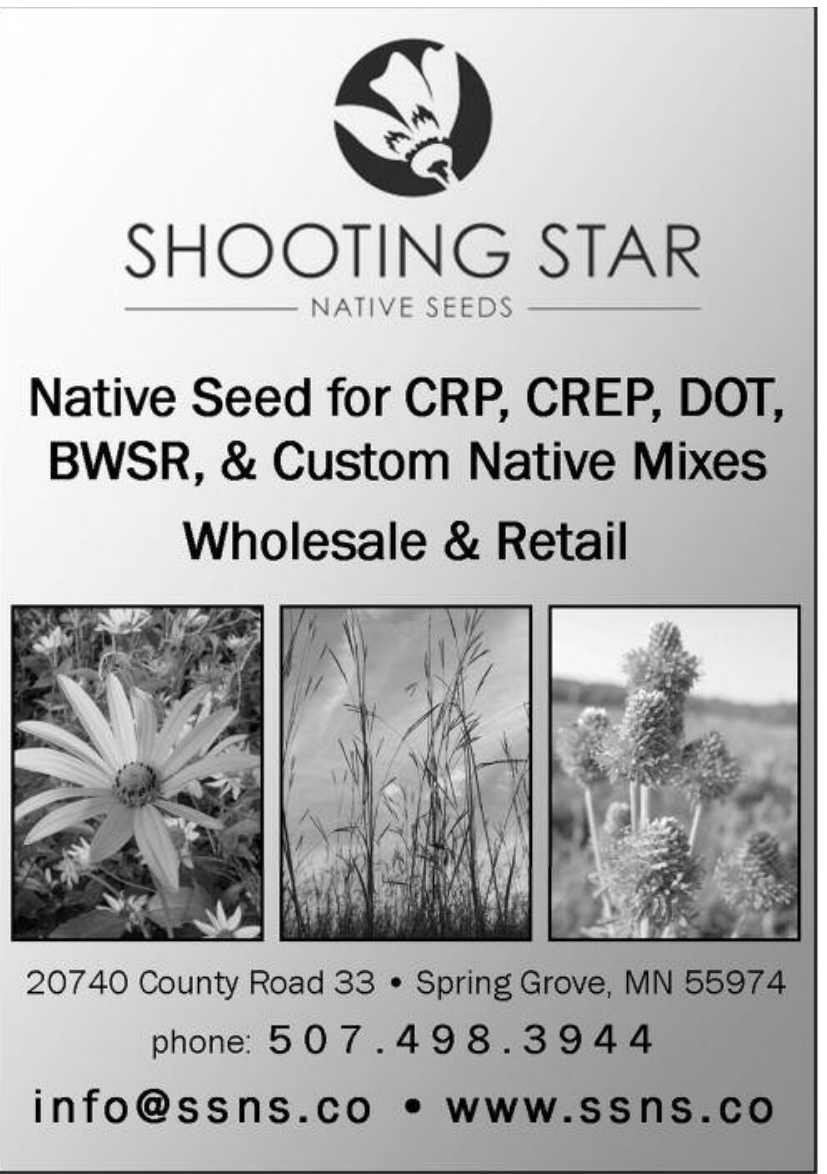

